\title{
DÜZENIN MEŞRULUĞU SORUNU BAĞLAMINDA İBNI HALDUN FELSEFESININ DEĞERLENDIRILMESi
}

\author{
Armağan Öztîrk \\ Kocaeli Üniversitesi \\ İktisadi ve İdari Bilimler Fakültesi \\ Araştırma Görevlisi
}

\section{Özet}

Makale kavramsal bir sınıflandırmanın da yardımıyla filozofu, düşünürler ve düşünceler dünyasında ait olduğu yere yerleştirmeye çabalar. Gelenekçi gerçekleri kabul eden, realist gerçeklerden hareket eden kişidir. Haldun'da modern bilimin ilk prototipi olarak göze çarpan sosyoloji realist olmaktan çok gelenekseldir. Filozofun tarih kuramı ideoloji-bilim ilişkisi bağlamında dikkate değer bir arkeolojik örnek durumundadır. Haldun mantıksal olmayan olayları gerçek olmadığı için eler. Onun mantıktan anladığı ise herkesin kendine yakıșanı yapması bağlamında ölçülülük ahlakını andıran bir yapma kültürünü anlatır. Kaldı ki filozof gerçeği makulde arayan bir ortak akılcı eğilimi edebiyatının her satıında korur. Kültürel dıșlayıcıllığın kıyısında, devrinin ve düzenin sahiplerine saygılı, adaleti egemenden yana ve devrimi meşrulaştırmayacak şekilde yorumlayan ve baskıcı asabiyeyi aklayan bir tutumu bilimselliğin ardına saklanarak savunur.

Anahtar Kelimeler: Teori, normatif teori, kurucu teori, uluslararası normlar, İbni Haldun.

Revisiting Ibn Khaldun in the Context of Rationalization of Establishment

\section{Abstract}

The article aims to locate the philosopher in the world of thinkers and ideas by using a conceptual classification. The one who accepts the tradition truths is a person who departs from the realist truths. The sociology of Haldun, which stands out as the first prototype of modern science, seems like traditionalist rather than a realist one. Philosopher's theory of history is a significant archaeological example in the context of relationship among ideology and science. Haldun ignores non-logical events by reason of that they are not real. What he understands from logic is a practice culture which reminds a moderation ethic in the context of subjects whose acts are proper, suitable and/or according to their nature. Besides, the philosopher secures an inclination of a common mind and/or public reason, which sees truth in the moderate in every line of his literature. In the outskirts of cultural exclusion, he defends an attitude, which is respectful toward the owners of his age and order, which reads justice in favor of the sovereign and avoiding a legitimating of revolution and which justifies an oppressive tension, in the cover of being scientific.

Keywords: Evolution, tradition, realism, theory of history, tension, alienation, Ibn Khaldun. 


\title{
Düzenin Meşruluğu Sorunu Bağlamında İbni Haldun Felsefesinin Değerlendirilmesi
}

\author{
"Kavrayamadı̆̆ı şeyi yadsıması insanlı̆̆ın geleneğidir" \\ İbni Haldun
}

\section{SUNUS}

Yazının nihai amacı tarih kuramcısı ve filozof İbni Haldun'u edebiyatı üzerinden düzenin onanması sorunu bağlamında değerlendirmektir. Genel bir çerçeve içinde İbni Haldun'un devrinin iktidar geometrisini meşrulaştıran bir siyasal sosyoloji tasarladığı savlanacaktır. Burada düzenin meşrulaştırılması sorunu olarak kristalize edilen iktidar yanlısı tutum ise tarihin hemen her döneminde varlığına rastlanılacak oligarşinin savunulması, yeknesak yapıdan uzaklaşanların ötekileştirilerek ayrıştırılması, değişimin yavaşlatılıp toplumsal statiğe kendini evrimci bir şekilde yeniden üretme imkanının verilmesi ayraçları ile bir siyasal ruhu ifade eder. Siyasal arkeolojik bir çalışma olan İbni Haldun sosyolojisi üzerine değerlendirme kavramsal meşruluğunu iki kabulden alır: $\mathrm{Bu}$ kabullerden ilki yukarıda kabaca betimlenen şekliyle Haldun sosyolojisinde siyasal muhafazakar tonda bir tutum ortaklığının olduğu şeklindedir. İkincisi ise bu bahsi geçen bağlamın düzeni meşru göstermeye yönelik tarihsel bir misyona karşılık gelmesidir. Düzenin meşruluğuna dair yargı da belli bir ön yargının türevi gibi durur. Düzen kavramı "iktidar" çevresinde yuvalanmış tüm siyasalsosyal bağlamı ifade eder. Bu bağlamın "eşitlik", “özgürlük” gibi bir dizi siyaset felsefesi nosyonu açısından halkın çıkarları ile yapısal bir ikilik içinde olduğu düşünülür.

Yazının izleyeceği kavramsal patika Haldun'da siyasal tutum birliği olarak düzen/iktidar yanlısı bakış açısının olup olmadığı ve eğer varsa da bu özelliğin onun kuramı bağlamında anlamı etrafinda şekillenecektir. Yanıtı aranan soru kısacası, filozofun tarihe ve sosyolojiye ait kapsamlı edebiyatının yöneten-yönetilen ilişkisine olan etkisiyle ilgili olacaktır. Bu olası ilgi evrimci- 
gelenekçi rasyonelliğin yeniden yorumlanması için bir geri besleme unsuru niyetine de kullanılabilir. Tüm bu genel gündem ayrıca sosyali nedensel ve gözlemsel bir şekilde açıklayan filozofun sosyoloji içindeki öncü rolüne paralel bir şekilde iktidar-sosyoloji ilişkisi tartışması ile kendini açacaktır. Yazarın genel kanısı Haldun sosyolojisinde "umran bilimi" içinde toplanan yarg1 ve ön yargılarının iktidarı destekleyen bir ideolojik duruşu temsil ettiği yönündedir.

İzlenecek yönetimin rahatsız edici yanları da vardır. Her şeyden bu kabil bir çalışma, eser olarak Mukaddime ${ }^{1}$ ve eser sahibi olarak Haldun'da anlam dünyasına dair batini ${ }^{2}$ (içsel-içte-gizli) bir gündemin olduğu ya da olabileceği ihtimali üzerine kurulmuştur. Demek ki filozof hangi kuramı dillendirilse dillendirsin, argümanlarını dünyayı muhafaza etme amacının çizdiği söylem çerçevesi içinde tutmaktadır. Böylesi bir temellendirme kavramlar dünyasının teori yanlı bir şekilde gözlemlenmesine yol açacaktır (Urry/Keat, 1994: 61-62; Burtt, 1964). Ama yazar olgucu bilim stiline sadık bir çözümleme yapmayı taahhüt etmemiştir. Dolayısıyla teori yanlı gözlem bir sorun olarak ele alınmaz. Muhtemelen dile getirilecek diğer iki eleştiri ise daha anlamlıdır. Haldun anlatısı son derece yoğun şekilde metin bağımlı bir şekilde kodlanmıştır. Mukaddimeye yapılan bolca atıf yazının takibini güçleştirebilir. Son olarak hemen her türlü Haldun okumasında bir biçimde kıyısına kadar geldiğimiz anakronizm sorunu dillendirilebilir. Bu tehlikeyi önlemek için Haldun'da olduğu varsayılan ve düzeni meşru gösteren düzen yanlısı gizli ideolojiden ne anlaşıldığı künye biçiminde kodlanmıştır. Ama bu tehlike ihtimalini de ihtiyatla karşılamak gerekir. Haldun anakronik okumaya müsait bir düşünürdür (Hassan, 1998: 32). Birçok modern düşünce, filozofun edebiyatı içinde cenin halinde bulunur. Dolayısıyla İbni Haldun'u modernin gözünden okumak değil, okumamak sorun yaratacaktır. Belki de esas sorun modern kavramlaştırmaları analitik araç olarak kullanması değil de, bu eylemin Mukaddime üzerinde

1 Bu metinde İbni Haldun'un Mukaddimesi'nin üç ayrı Türkçe çevirisi ile Rosenthal'ın İngilizce çevirisi esas alınmıştır. Turan Dursun çevirisi için (Haldun, 1997a ve Haldun, 1997b), Zakir Kadiri Ugan çevirileri için (Haldun, 1990a, Haldun, 1989b, Haldun, 1989c), Süleyman Uludağ çevirisi için (Haldun, 1988a ve Haldun 1991b), son olarak Rosenthal çevirisi için (Khaldun, 1989) kısaltmaları kullanılacaktır.

2 Mukaddime'nin batini yanının deşifre edilmesi girişimi, kendiliğinden İbni Haldun'un ezoterik (dereceli) bir bilgi/bilme anlayışına sahip olduğu anlamına gelmez. Haldun "çeşitli bilgilerin belli kültür düzeylerine ulaşllabilenlerce anlaşılabileceği gerekçesiyle, azar azar, aşamalarla verilmesi” şeklinde özetlenebilecek bir batinilikle değil, yalnızca kuramını düzenden yana olmak gibi bir siyasi/felsefi kaygının ardına gizlemesi bakımından bir batinilikle itham edilmektedir. Batinilik ezoterizm eş anlamlılığı için bkz. (Akın, 1998). 
yapılmasındadır. Mukaddime çok bilinen ama az okunan bir eserdir çünkü (Hassan, 1998: 15). Yine de Haldun'da olduğu varsayılan düzen yanlısı meşrulaştırıcı stil aşağıda betimlenmiştir. $\mathrm{Bu}$ betim makale savlarının denetlemesini amacinı da kolaylayacaktır.

Haldun'da düzen yanlısı ideolojik tavır alış bir dizi belirteç sayesinde görünür hale gelir: Haldun sosyolojisi geçmişin aklını bugünün aklı karşısında yücelten (1), alışkanlıklara, kelimelere dökülmemiş duygusal anlaşmalara yatkın (2), özgürlükten kendi gibi olmak bakımından özgünlüğü anlayan (3), korumak ile dengeli değişim arasında bir devinim/dönüşüm stilini benimseyen (4), doğuştan gelen statüleri, aşırı sıradüzeni ve vesayetçi yetkiyi onaylayan (5), organik toplumcu (6), dünyayı sistematik olmaktan ziyade yerelci bir şekilde algılayan (7), uygar insanı mayası gereği bozuk/kusurlu sayan (8), devleti toplumsal birliğin, hukukun ve ahlakın kaynağı olarak onaylayan (9), ama bu onaylamayı sivil cemaatçi bir karşı bağlamla dengeleyen, dolayısıyla devlet kadar toplumu da doğal gören (10), her gerçek olan rasyoneldir şeklinde (11), doğalcı onayıcı bir kurguyu ülküselleştiren, (12), ortalamaları bulmak kaygısını önemseyen (13), bir eşitsizlikçi dünya görüşünü yansıtır.

\section{IBNI HALDUN FELSEFESINDE TARIH KURAMI VE GELENEKÇiLIK}

\section{Tarihte Nesnel Yasalar Var mı?}

Gerçekliğin algılanışa dair epistemolojik ve ontolojik tartışma Haldun sosyolojinde yöntembilimsel bir ikiliğe dönüşür. Realist algısallığın ${ }^{3}$ betimleme zemini olarak kabul edildiği bir kavramlaştırma düzeyinde, filozofun siyasal sosyolojisi, en azından yüzeysel düzeyde determinizm kıyısında bir olgucu illüzyon yaratır. "Yüzeysel" sıfatı Haldun'un neden-sonuççu kesincilik konusunu ifade etmedeki yetersizliğinden çok, determinizmi yerelci bir rölativizm ile dengelemesi 1srarını anlatır (Becker/Barnes, 1961: 267 vd). İbni Haldun sosyolojisi, "toplumsal yaşamın içerdiği etkinliklerin temelde pratik bir nitelik taşıdığı ve doğal zorunluluklardan kaynaklandı̆̆ı" şekliyle özetlenebilecek bir doğal toplum ${ }^{4}$ kozmolojisine yaslıdır. Bu bağlamda Haldun'da olguculuk birbirini tamamlar şekilde üç anlama gelecektir: (1) Toplumu kurmaya yönelik etik rasyonel temelli teorik akıl yerine, toplumu

3 Realizm için bkz. (Keat/Urry, 1994: 34-50).

4 Doğal Toplum için bkz. (Sunar, 1979: 2-3). 
betimlemeye yönelik bir pratik aklı ve araçsal rasyonelliğ $i^{5}$ tercih eder Haldun. Haldun'da araçsal akıl, bir konuyu ele alış tarzı kadar edebiyatını oluşturma biçimi üzerinde de etkilidir. Filozofun yegane amacı bir siyaset felsefesi inşa edebilmektir. Ama bu inşanın kendi yetkinliğine ulaşması için öncesinde bir tarih felsefesi, daha öncesinde bir kültür bilimi (umran bilimi) ${ }^{6}$ ve en önce bir tarih yöntemi yaratması gerekmektedir. Haldun'daki bu dört özlü kesitin her biri bir öncekinin amac1, bir sonrakinin aracı durumundadır. Filozof edebiyatını, işlevsel-araçsal bir aklın işletilmesi sırasında ortaya çıkacak olağan sırayı uyumlu bir bağlamda yaratmıştır (Rosenthal, 1967: 42-65). (2) Haldun'da tarihin nesnel belirleyicileri vardır. İnsan gerçekliliğini tarihi materyalist bir içerikle yorumlar (Issawi, 1969: 17; Falay, 1978: 14-16; Hassan, 1998: 141144, 24, 162; Meriç, 1977: 158, 241, 258 ). Özellikle iş bölümü ve insan emeğinin tarihe katkısı noktasında alt yapı-üst yapı retoriğini andıran bir dizi nesnel ayraca atıf da bulunur filozof (Ülken, 2000: 257; Kıvılcımlı, 1989: 35). Olaylar nehirlerin üzerinde akan tekneler, gemiler gibidir aslında ve tarih, insanlığın yazgısı ile birlikte bu bağlamın içinde akmaktadır. (3) Saf/salt ampirizmin doğal sonucu olarak olandan olması gerekene geçmez Haldun. Kuramı olması gerekene dair her türlü sanıyı gerçeğin bozulmuşu olarak dışlayan bir tınıyı içselleştirmiştir (Geertz, 1964: 50, Parsons, 1969: 25-49). Ancak bu dışlama "tarih yönteminin kodlandığı" sırada (Haldun, 1997a: 64132) açıkça bir iktidar yanlısı tutuma dönüşür. Bir anlamda olana dair zorunlu ilgi ve olması gerekene yönelik anlamlı ilgisizlik, olanın olması gereken olduğu bir düzen aklayıcılığını beraberinde getirir. Olgunun ötesine geçmenin İbni Haldun için pozitif bir anlamı yoktur. Filozof zorunlu kalmadıkça dünyayı algılama biçiminin sınırlarını belirleyen olgular dünyası dışına çıkmaz. Tabii bu sonuç bizi ikili bir yorumun eşiğine kadar götürür. Her şeyden önce deneysel olgusal felsefesi ile bu felsefeye hayat veren yaşamı arasında bire bir örtüşme vardır Haldun'un. Filozof Haldun oldukça çalkantılı, siyasal açıdan inişli çıkışlı ve gezip görmeye dayanan serüvenci bir hayat sürmüştür. Sosyal teorisinin ardında güçlü bir yaşam pratiği vardır (Kızılçelik, 2006: 66). Bu da bizim ampirizm ile olgucuk arasında kurduğumuz bağda ne kadar haklı olduğumuzu gösterir. Peki deneyime ve gözleme dayalı Halduncu siyaset felsefesi neye yol açar? Haldun olguları incelemeye değer gördüğü sosyal teorisinde bu olguların

5 Araçsal rasyonellik kavramı için bkz. (Beatty, 1983: 484-495; Chirot, 1985: 181-195; Maclntyre, 1988).

6 Haldun sosyolojisinin doruğu niteliğindeki Umran özü itibariyle topluma ait her şeyi kapsar ve bir bilimler genel bilimi olarak işlev görür. Ayrıca Halduncu terminoloji içinde Umran toplumsal durumu değişen zaman ile birlikte ele alan bir genel çerçeveyi yansıtır. Yorum için bkz. (Corbin 2000: 63 ve Lacoste, 1993: 170). 
uzun vadede (ya da çevrimsel tarihin bir tam döngüsünde) birbirine dönüşerek insanlığ 1 başladığ1 yere götürdügü düşünmüsstür. Ona göre suyun suya benzemesinden daha çok geçmiş geleceğe benzer (Haldun, 1988a: 210, Haldun, 1990a: 20, Haldun, 1997a: 76). Her şeyin ne kadar çok değişirse değişsin yine eski haline dönüşeceğine dair bu kapalı tarih anlayışı okuyucusuna oldukça gelenekçi bir siyasal mesaj verir. Bu mesaj da kolaylıkla tahmin edileceği gibi en çok düzeni herkes adına yöneten oligarşinin işine yarayacaktır.

Tarihi perspektif açısından olguculuk, dünyayı muhafaza etme, değişecekse de yasaları bilindiğinden önceden kestirilebilen, hatta kontrol edilebilen bir biçimde değişmesi amacını kendine şiar edinmiş bir bilim yapma anlayışını anlatır (Marrow, 1994: 14 ve Porter, 1990). İbni Haldun ise, modern bilimlerin öncülerinden biri olarak, (Azmeh, 1994: 384; Edwards, 1970: 109; Issawi, 1969: 16) "insan faktörünü" iktidarsızlaştıran bu kabil bir bilgi kotarma stilinin geleneksel dünyadaki en rafine olmuş örneğidir (Gibbb, 1963: 1-17). Böylesi bir kristalize olma, beraberinde kabulleri ile uyumlu siyasal mesajlar taşıyacaktır. Haldun determinizminin vardığı yer, özgür iradeli insan varlığının ve bu özgür varlıktan doğan her türlü insani çeşitliliğinin reddi ile ilgilidir. İnsan Haldun tanıtlamasında olduğu üzere bir veya birkaç sosyal sürecin, dönemin ve koşulun zorlamasıyla gerçekleşiyor ve gerçekleştiriyorsa, kendi üzerindeki sınırların aksine gidebilme ve fark yaratabilme şansından yoksundur demek ki. Oysa filozofun üzerine felsefesini kurduğu tarih sayısız isyan ve devrimsel değişimi içinde barındırır. Haldun'daki olgucu nosyon, siyasal edebiyatını ileride ayrıntılandırılacağı üzere "evrimcilik", "düzen koruyuculuğu" ve "ötekileştirmeye" götürür.

Olguculuk ile düzen yanlısı tavır alış arasındaki kavramsal örtüşmenin Haldun örneği açısından bahis konusu edilmesi, makalenin üzerine inşa edildiği ana perspektifi destekler niteliktedir. Yalnız bu aşamada pozitivizm aleyhine ve mistizm lehine geniş̧̧e bir parantez açmamız gerekecek. Haldun' da pozitivizm kadar onla çelişik başka akımların ve algı stillerinin izlerini de görmekteyiz. Hikayeci uydu yazarları, olayların arkasındaki olguları anlayamamak ve anlatamamak ile suçlayan filozof, (Haldun, 1997a: 67-68) yazı düzeneğinin genelinde gerçeklerin ardında başka gerçekler arayan, var olanı, olayları değil de onların arkasındaki asıl olayları vurgulayan bir anlayışla çıkar karşımıza. O halde şu ara problemle hesaplaşmak zorundayız: İbni Haldun sanıldığı gibi gerçekten bir olgucu veya bu tür bir bilinmeyeni arama anlayışının öncüsü mü, yoksa biz ondaki üzeri determinizm ile sıvanmış "mistik" karışık ruh halini yanlış bir şekilde pozitivizm olarak mı yorumluyoruz? Belki de Haldun, Comte'un değil, mağara kuramıyla tam da böyle bir gizemciliğe hizmet eden Platon'un kulvarındadır? (White, 1960: 123-124) 
Kahinler, peygamberler, yıldız falcıları ve sihirbazlardan bahsederken açıkça gerçekliği algılanabilen (ampirik) ve kavranılabilen (sezgisel) diye ikiye ayıran düşünür, belli yeteneklere sahip insanların belli durumlarda ontolojik açıdan daha üstün (üste) olan bu varolanlar dünyasına ulaşabileceğini belirtir (Haldun, 1997a: 264-265). Bu belirtme aynı zamanda dünyanın ve insanın mistik tarzda algılanması noktasında Haldun'a çokça yakıştırılan materyalist bilimsellik için bir aykırı unsur niteliğindedir. Üstelik Haldun gizemciliğini sıra düzenci bir evren tablosu ile birlikte sunar. Böylelikle Aristoteles'in yaptığ 1 ve ortaçağ İslam ile Hiristiyan skolastiğinin sahiplendiği gibi (Hilav, 1975: 54; Carlye/Carlye, 1962; Henry, 1967: 227-257) derecelendirilmiş bir varlık anlayışı ve eşitsizlikçi bir felsefeyi benimsemiş olur. Gerçekliğin doğal olarak bir alttakiler-üsttekiler ayrımını ifade ettiği yorumu, tarih boyunca her vakit, insanlar arasındaki eşit hatta denk bile olamayan ilişkinin meşrulaştırılmasında kullanılmıştır. Ve doğal olarak her türlü eşitlikçi karşı çıkışın kusurlu ve kesinlikle insan doğasına aykırı gösterilmesinde. Tabii böyle bir ontolojinin siyasete yansıması, aristokratik, oligarşik tüm olası seçkinci yönetimlerin kurulmasının ve yaşatılmasının kolaylaştııılmasında gizlidir. Konumuz bağlamı açısından Haldun'un aristokratik siyasete yatkınlığı iki biçimde formüle edilebilir: Her şeyden önce düşünür, sosyal hareketlenmeyi sıra düzenci katmanlaşma içinde açıklayan, bir anlamda da olumlayan "seçkinler kuramı" perspektifine ${ }^{7}$ yakın bir üç kuşak yasasına sahiptir. Devletin yaşam süreci dededen babaya, babadan oğla üç kuşak içinde yaşlanır ve yaratıcı ruhunu yitirtir. Doğal ve yetkin olan yaşlı erkeklerin yönetimidir (Haldun, 1997b: 7; Haldun, 1990a: 432; Haldun, 1988a: 505). Ayrica filozof "bilen" insanın yönetmesi gerektiğini vurgulamaktan kaçınmaz (Haldun, 1997b: 43). Bu vurgu “işbölümünü” doğal ve gerekli gören organizmacı bir tanıtlamanın ürünü gibi durur (Boulakia, 1977: 1106). Haldun'da işbölümü hayatın zorunlu bir parçasıdır. Yardımlaşma gibi doğaldır işbölümü. Bazıları yönetir, bazı diğerleri yönetilir; bazıları güçlüdür, bazıları ise zayıf (Haldun, 1990a: 100-1, Haldun, 1989b: 441; Haldun, 1997a: 139-140; Haldun, 1988a: 271-2).

İnsanların derece derece sıralandığı ve tanrıya yakın olanların daha üst konumda olduğu ve(veya) böyle bir konuma doğru hareket edebildiği sav1 tersine yorumlandığında acaba insanlar aşağıya doğru da hareket edebiliyorlar $\mathrm{m} 1$ sorusunu gündeme getirir. Üslubu içinde çoğu kez biçimsel, ancak bazen açıkça ve kendisine onu bir konu, bir anlatı olarak seçmişçesine ötekileştirmelere giren Haldun için böyle bir sorunun yanıtlanması ayrıca

7 Haldun'un üç kuşak yasasının seçkinci anlayış içinde değerlendirilmesi için bkz. (Cairns, 1971: 324-326, 331; Duverger, 2002: 164). 
- Ankara Üniversitesi SBF Dergisi • 63-1

önemlidir. Eğer insan hayvan ile tanrı arasına gerilmiş bir ip ise ve bazı insanlar tanrıya daha yakınsa bazı diğer insanlar neden hayvanlara yakın olmasın ki? Örneğin Aristoteles köleleri hayvanlara en yakın ve hayvanca yaşamaya en layık varlıklar olarak görürdü (Aristoteles, 1990). Peki kentlileri, Arapları, çok yiyenleri, İsrail oğullarını vb. bir çok şeyi, kimseyi beğenmeyen, onları (insanları) eksiklikle ve yetkinsizlikle suçlayan Haldun, (Haldun, 1997a: 254, 298-299, 319-320, 347-348) bu yargılarını ne tür bir insan anlayışına dayandırarak savunur? Herkesin haddini ve yerini bilmesi, katmanına, derecesine, kabilesine, bu tür belirli ve çoğu kez de değişmez sosyolojik kategorilerin kısıtlara göre davranması konusundaki ısrarı onu, ölçülü-gelenekçi bir betimleme ve yorumlama kulvarına sürüklüyor. O halde bilginin nasıl elde edileceğine dair bilgi kuramsal problem, Halduncu çizgiyi skolastik evren ve insan anlayışına, o da doğal olarak düzen yanlısı bir siyasal duruş ile ayrımcı bir sosyal tutuma götürüyor diyebiliriz.

Haldun'u önce realist-materyalist bir olgucu, ardından da sıra düzenci, mistik bir tinci olarak yorumlayan, uçlara dikkat çekerek ortayı temizlemeye yönelmiş yukarıdaki panorama, İbni Haldun'un materyalist-ampirik stil ile mistizmi sınırladığı, ama bu sinırlamanın da aynı zamanda bir tanıma olduğu şeklindeki "sentezlenmiş" argümanı açıklar niteliktedir. Böylesi bir açıklama ile biz, onu, zamanındaki felsefeyi mistizminden temizlemek isteyen bir öncü materyalist olarak yorumlayan görüsslerin (Mahdi, 1957: 198; Kurtoğlu, 2006: 43-65) tehlikeli aşırılığından, ondaki felsefenin materyalist-realist bir tutumla mistik-tinci düşünceyi sınırladığg (Rabi, 1967: 42-43) yönündeki daha "makul" bir iddianın kavramsal güvenliğine sığınmış oluruz. Bu sığınılan yerin görece güvenli bağlamı içinden, adını söylemeksizin sosyolojiyi betimleyen, kuran Haldun'un (Bağce, 2005: 204) yöntem olarak tümdengelimi önerdiği, (Haldun, 1997a: 70) sosyal olayları yasalara bağlamayı ilkece onayladığı, (Hassan, 1998: 157) göreli bir determinizm ile ampirik bir rasyonalizm arasında sistematik olmayan gözlemlerden sosyolojik yorumlar çıkarma yolunu izlediği söylenebilir (Sorokin, 1962: 19). Tabii Haldun üzerinden yürütülecek bir yöntem tartışması filozofun felsefeyi canlandırmaya çalıştı̆̆1 gerçeğinin ön bilgisi ile birlikte yorumlanırsa daha anlamlı hale gelecektir (Mahdi, 1957: 72). 


\section{IBNI HALDUN ANLATISINDA DÜZENIN MEŞRULUĞU}

\section{Tarihin ve Tarihte Ínsanın Yanlış Okunuşu: İdeoloji- Bilim Illişkisi}

Kuramsal tarihini örneklerle açmaya çalıştığı pasajlarda düşünür, bir başka düzeni meşrulaştırıcı belirti ile karşımıza çıkmaktadır. Birtakım antipati ve sempatileri vardır Haldun'un. Ve dolayısıyla tarihi olaylar karşısında açıkça taraf tutar. Özellikle İslam uygarlığı, Arap toplumu ve Berberi varlığının bahis konusu yapıldığ durumlarda, yani kendi ile ilintili dünyaya karşı bir korumakollama çabası içine girmektedir. Dahası ve konumuz açısından önemli olanı, bu çabanın özel olarak üst sınıftan gelenleri ve onların eylemlerini ön plana çıkaran kaba bir aklamacılığa dönüştüğü gerçeğidir. Filozof, Abbese adlı prensesin kölesiyle cinsel ilişkisi, Kadı Yahya'nın oğlancıllı̆ ${ }_{1}$ ve Harun Reşit'in zevk düşkünlüğü (Haldun, 1997a: 88-94) konularında tarafsızlığı bir kenara bırakarak belirgin bir aristokratik ahlak savunuculuğuna girişir. Ona göre hikayeci tarih yanlış ve yanlıdır. Mantığın süzgecinden geçmemiş bir yığın olay yazıcılarının ve yapıcılarının kişisel, keyfi gayretleri sonucu objektif tarihimizin parçası haline gelmektedir. O halde mantık dışı, insan usunun kabul etmeyeceği olay ve olay iddialarına karşı uyanık olmalıdır tarihçi. Kanıtlara dayanmayan, değişimin farkında olmayan, neden-sonuçtan yoksun uydurma yaklaşımlar tarihten temizlenmelidir. Gerçek bir tarihçi yönteme başvurur; sağlam ilkeleri doğrultusunda tarihi olayları usa vurur (Haldun, 1997a: 67, 74, 95, 108; Haldun, 1990a: 65-6; Haldun, 1988a: 240-1). Böylelikle olaylar ile niyetler arasına sağlam bir set çekerek, iki dünyayı birbirinden ayırabiliriz. ${ }^{8} \mathrm{Bu}$ tür bir yarg1 her ne kadar konunun perspektifi açısından tarihin nesnelleşmesini sağlasa da, ya da devrinin tarihçilerini yeterince eleştirel olmamakla suçlayıp eleştiri ve felsefe temelli eleştirel düşünceye meşruluk sağlasa da, (Kurtoğlu, 2006: 55) aslında ideoloji-bilim ilişkisi bağlamında bugünde tartışılan ${ }^{9}$ sorunlu beraberliğin daha da kurumsallaşmasına yardım etmektedir.

8 Yorum için bkz. (Uludağ, 1988: 110-1).

9 Bugün ideoloji tartışması, toplum bilimlerin nesnelliği, neo-liberal ekonomi politiğin hegemonik üstünlüğü, aydınların düşün dünyasındaki yeri ve alt yapı-üst yap1 ilişkileri gibi konular üzerinden tartışılmaktadır. İdeoloji-Bilim ilişkisinin bilim felsefesi-bilgi sosyolojisi odaklı kapsamlı bir incelemesi için (Habermas, 1993) ve (Plamenatz, 1970). İdeolojiyi bilimin bozulmuş bir versiyonu olarak gören anlayış için bkz.(Parsons, 1971: 349-351). İdeolojinin alt yap1-üst yapı bağlamında ele alınması bağlamı için (Poulantz, 1988: 11-39). 
Tarihin nesnelleşmesi bağlamındaki tartışmada tartışmayı derinleştirici kavram "akıl"dır. Rasyonel oldukça tartışmalı bir kavramdır çünkü; ${ }^{10}$ çıkardan bağımsız akıl yoktur aslında. Dolayısıyla her akıl ya da akıl yürütme bir çıkarın emrindedir (Maclntyre, 1988; Gellner, 1992). Tüm bunlar 1şığında bir kişii, bir düşünür ya da bilim adamı, ideolojik-öznel bir saikle hareket ederek ve amacını rasyonelin içine gizleyerek elde ettiği sonucu bilimselin parçası haline getirebilir. Haldun sosyal bilimlerin öncüsüdür derken, onun böylesine pürüzlü bir bilim yapışın da öncüsü olabileceğini hatırda tutmamız gerek. Çünkü mantık dış1 olayları tarihin dışında tutmak isteyen düşünür, farkında olarak ya da olmayarak "ona göre" mantık dışı olayları bu biçim içinde değerlendirmektedir. Ayrıca Haldun'un aksine, mantığın bir ölçü olarak kullanılmasının tarihin nesnelleşmesine olumsuzlatıcı nitelikte etki yapabileceğini düşünülebiliriz. Çünkü Haldun'un izinde gidersek tarih eşittir mantıklı olayların toplamı olacaktır. Oysa tarih yalnızca olayların toplamıdır. İnsanlar mantıksızca, akıllarını hiçe sayarak, duygusal ve ani hareketlere girişebiliyorlar. Bu durumda ne yapacağız? Olan bir olayı onu yapanlar o sırada mantıklarıyla hareket etmedikleri için olmamış mı kabul edeceğiz? Demek ki mantıksız olaylar da olmuş olabilir. Kaldı ki Haldun için mantık, bir tekniğin ötesinde ahlakı olgunluğu, zihni yetkinliği anlatan bir işarettir. İnsanın kendisine yakışmayan şeyi yapması bir mantıksızlıktır mesela. Bu kendine yakışan da katmanlı bir toplumsal coğrafya içinde anlamlandırılacak niteliktedir. İnsan toplumsal statüsüne uygun bir ahlaki çerçeve içinde hareket eder Haldun'a göre. Köle köle gibi ve efendi efendiye yakışırcasına davranır. Dolayısıyla tüm insan eylemleri için ve her zaman herkese karşı eşit bir evrensel ahlaktan bahsedemeyiz. Ahlakiliğin anlamı ve insan bilincine buyruklar biçiminde etkisi sıradüzenin çeşitliliğine paralel bir çeşitlilik gösteriyor. Evrensel ahlakın derece mantığı aracılı̆̆ıyla sulandırılması, ahlak insanın değeri ve insanın diğer insanlara vermesi gereken değeri standartlaştırdığından, daha değerliden daha az değerliye bir insan algılayışına yol açıyor. Hem bu sonuç toplumsal statüleri daha yüksek insanlarının daha ahlaklı olduklarına dair düzeni meşrulaştırıcı alt bir öğeyi de içinde barındırıyor. Abbese niye kölesiyle cinsel ilişkiye girmez? Çünkü o bir Halife kızıdır. Soylu olmanın mutlak kusursuzluğuna sahiptir

10 Tartışmanın bir boyutu doğru bilginin akılda olduğu ve(veya) aklın doğru bilgi konusunda tek ölçüt olduğu yargılarını ifade eden "rasyonalizm", bir diğer boyutu ise, aklın göreceliği, evrensel akıl, aklın deney gerçeğini işlemedeki tartışmalı rolü, çıkar-akıl-değer bağlantısı, uzun erimli ve kısa erimli çıkarlar arasındaki gerilim ve araçların amaçlara uygunluğu olarak akıl kullanımının konuyu özetlemedeki potansiyel başarısı gibi noktalar açısından doğrudan "akıl” kavramı çevresinde dönmektedir. Bu bahis için bkz.(Demir, 2000). 
sonuçta. Tüm bu fotoğraf içerisinde gözlerden kaçırılmaması gereken bir diğer nokta ise ahlaka yüklediği anlamın tümüyle düzenin dolayısıyla dinin çizdiği paradigmanın içerisinde olmasıdır. Din yalnızca insanın eylemselliğini sınırlayan bir çerçeve değil, aynı zamanda o çerçevenin içerisinde nelerin yapılabileceğini de açıklayan bir anlam reçetesidir. Haldun o reçeteyi bir a piori bilgi olarak kabul ediyor; bir anlamda diğer tüm ve sonraki yargıları için öncüleştiriyor. Tüm bilimselliğine karşı mümin kişi olarak yazmış ve tarih kuramını inancının sınırları doğrultusunda şekillendirmiştir (Ahmed, 2002). ${ }^{11}$ Neden erkek ve kadın arasındaki cinsel etkileşim, örnek olayda olduğu şekliyle bir ahlaksızlığı işaret etsin ki? Neyin ne kadar ahlaki olduğuna karar veren ya da verilmiş kararları meşru kılan neden din, dini gelenek? Ahlak niye haz değil de yasak, istem değil de itaat? Çünkü Haldun'un benimsediği tanrıcı-gelenekçi hakim düzen için olması gereken ve beklenen bu. Düşünür tutumuyla gelenekçiyi gelenekçi olmayandan ayıran temel özelliğe uygun bir davranış sergilemekte. O da şu ki, özel ve ayrıcalıklı bir nedeni yoksa devrinin kurumlarını doğal görür. Onların insan üzerindeki kısıtlarını da tabii. ${ }^{12}$

\section{Doğallık ve Adalet}

Haldun'daki gelenekçi tını satır aralarına gizlenmiş, bir anlamda kitabın hamuru içinde eritilmiş çok sayıda küçük öğe ve belirteç sayesinde izlenebiliyor. Bu öğeler içinde en etkili olan "doğallık" kurgusudur. Haldun anlatısının çeşitli yerlerinde devletin ve devlet egemenliğinin ne kadar doğal olduğundan bahsediyor (Haldun, 1997a: 336; Haldun, 1988a: 355). Aslında tüm

11 Haldun'un din kurumuna bakışında iki önemli ayrıntı ön plana çıkmaktadır. 1) Öncelikle filozofun dinci paradigmayı savunuşu belli doğal sınırlar içinde söz konusu olmaktadır. Dini korusa kollasa da, savlamasını hiçbir biçimde bu kurumun devlete üstünlüğü noktasına getirmiyor. Haldun "laiklik" ile "dinin devlet için araçsallaştırılması" tutumları arasında bir yerde durmaktadır. Ona göre, "Din işlerine bakanlardan birinin eline, devlet egemenliği geçmişse, bu geçicidir ve dinsel nedenler dişında bir nedenden kaynaklanır" (Haldun, 1997a: 112) 2). Ayrıca filozof tarih kuramını şekillendirirken neyin tarihsel olduğu noktasında dinsel haberlere akıl karşısında bir ayrıcalıklı koruma sağlıyor. Yani dinsel haberler akla, mantığa ve doğa yasalarına aykırı olabilirler. Yeter ki güvenilir kişiler getirsin onları (Haldun, 1997b: 128).

$12 \mathrm{Bu}$ tartışma bağlamında Haldun'da, bir muhafazakarlık nüvesi olarak doğacılığın izleri görülmektedir. Doğacılık, “doğanın dışında hiçbir şeyin var olmadığını ileri süren, buna göre her şeyi deneyine ulaştığımız doğal olaylar zincirine indirgeyen öğretidir” (Timuçin, 1994: 78). Ayrıca doğacılık Haldun'nun benimsediği Platonik modelde doğal olanın kutsal ve özgün olarak görülmesi anlamına da gelecektir. 
Ankara Üniversitesi SBF Dergisi • 63-1

toplumsal kurumlar ve toplumsal bağlamlar onun için doğal. Siyaset felsefesinde ve bu işin modern uzantısı siyaset biliminde eğer taraf olarak bir durumu ya da bir kurumu meşrulaştırmak istiyorsanız, yapmaktan sakınmamanız gerekecek ilk şey, bu meşrulaştırmada sağlamlaştırıcı unsur olarak ve sıkça "doğal" kelimesine başvurmak olmalıdır. Çünkü "doğal” bir tamlayan öğesi şeklinde iş gördüğü durumlarda, tamladığg kelimeye ve onun varlıksal gerekliliğine neredeyse sonsuz bir destekleme anlamı katıyor. $\mathrm{Bu}$ gerçeği çok erken çağlarda fark etmiş gelenekçi düzen yanlısı anlayış ise, tarihsel seyri bakımından hemen her şeyde bir doğallık görür. Bir kuruma nitelenen doğallık sıfatı çoğu kez o kurum için dokunulmazlığı ifade eden bir etiket. Demek ki "doğallık" vurgusu mimlenmiş bir muhafazakarlık işaretidir (Popper, 2000: 81). Filozof Haldun ise bu işareti içinde yaşadığ sosyolojide betimleyici ve benimseyici unsur olarak kullanmaktan kaçınmıyor.

Bir diğer gözden kaçırılmaması gereken nokta, Haldun'un bir politik ahlak öğesi olarak "adalet" düşüncesi karşısındaki israrlı tutumu. Devlet adamlarının adalete uygun, adilce yönetmelerini istiyor hakimi oldukları toplumları. Adil devlet adamı klasik ahlak anlayışına göre formüle edilmiş. Adil yönetici tanrıya karşı sorumlu olan haktan çok ödevi olan "sürünün çobanı" (Haldun, 1997b: 224). Adaleti yorumlama şekliyse tamamen işlevsel. Adalet bir işe yaradığ 1 için değerli onun gözünde. Adalet olmazsa, toplumsal ve ekonomik gelişme olmaz. İnsanlar haksızlık tehlikesi karşısında çaba göstermez, atıl durumda kalmay1 tercih ederler (Haldun, 1997b: 211-212). Kabaca bakıldığında adalet düzen içindeki ayrıcalıklı yerlerini korumak kaygısındaki üst sınıflarının hareketlerini kısıtlayarak, doğrudan bu sınıfların çıkarlarına hizmet eden düzen yanlısı bakışı zedeliyor. Haldun'un iktidar yanlısı biri olarak adaletten bahsetmesi bir çelişki o halde. Ama tarihsel bağlamında "adalet" mitosunun eşitsizlikçi düzenin mağdurlarının işini kolaylaştırdığını söylemek o kadar da mümkün değil. ${ }^{13}$ Adalet Marks'ın deyimiyle üst yapı içerisinde bir çatlak belki de, ancak aynı zamanda bir önleyici tedbir. Düzenin daha uzun yaşamasını sağlıyor. Düzenin sahipleri için bir kırmızı çizgi. Oligarklar o çizgilerin öte tarafına geçmeseler bile insanlık yeterince eziliyor. Ayrıca neyin adil olup, neyin olmadığı, hangi davranışın çizginin ne tarafinda kaldığı devletle bitişik bir tarihsel ve ideolojik geçmişi olan din kurumunca belirleniyor. Üst yapının ayrıcalıklı üyeleri din adamları,

13 Adalet eşitlik (orantılı ya da mutlak) ile rasyonelliğin (objektif, önceden belli, keyfi olmayan) siyasal felsefedeki kesişimini ifade eder. Ama adalet en azından toplumsal mücadele bağlamında benlik çıkarını kamufle eden, insanların çıkarlarını kendi çıkarı olduğu için değil de, tüm insanlar için adil olduğu savunmasına olanak tanıyan bir imkandır. Bkz. (Güriz, 2001: 16-18). 
adaleti simgeleyen olurlar ve olmazlar çizgisini düzene en az zararı verecek şekilde çiziyor. Dolayısıyla çok istisnai durumlar hariç, devlet hemen her zaman adaletin çerçevesinin içerisinde ve öyle bir çerçevenin içerinde olmanın verdiği rahatlıkla zulümlerine devam edebilmektedir. Eşitlikçi doğaları ile alternatif adalet anlayışları ise, bu zulmün en büyük mağdurlarıdır. Ayrıca devlet açıkça adil olmasa dahi, adalete siyasal kuramlarında bir çözümleme ve meşrulaştırma aracı olarak yer veren filozoflar, iktidara itaati salık verirler. Örneğin Haldun'a göre halife sapık olsa dahi ona baş kaldırılmamalıdır (Haldun, 1997b: 86). Halifenin yanılmaz dünyevi otorite olarak mutlak üstünlüğüne yapılan vurgu Haldun'un halifeliği meşrulaştırmak için özel bir gayret göstermediğine dair popüler tespitin ne kadar da yanıltıcı olduğunu ortaya koyar.

Haldun'un adalete bakışı, İslam dünyasında adaletin yerine dair kuramsal bir tespit aracılığıyla derinleștirilebilir. Bir politik erdem olan adalet konusunda İslam düşüncesi, Yunan ve Hıristiyanlık anlayıșlarını sentezlemiş görünmektedir. Bilindiği üzere Yunan ahlakı akıl merkezli ve adalet odaklıdır. Buna karşılık Hıristiyanlık ruh merkezli ve merhametçi bir tınıyı benimsemiştir. İslam ise en azından teorik bağlamda adalet ile merhameti, akıl ile vicdanı sentezlemiş görünür (Ülken, 2001: 33-39). İslam'da adaletin merhametle kesişimi, adaletçi nosyonun yerleşik çıkarlarla dengelenmesi gibi bir tali sonucu beraberinde getirir. Ama bu sonuç "adalet" fenomenin özü ile uyumludur. Çünkü adalet siyaset felsefesi açısından ideal düzen arayışında sadece özgürlük veya sadece eşitlik peşindeki anlatılara karşı bir dengeyi, her iki ilkeyi "toplumsal bütünlük", "ölçülülük", ve "ortak akı1l” bağlamında yumuşatan, düzenin devamlılığı noktasında bir uzlaşmayı yansıtır.

\section{Güç Ahlakı ve Asabiyyet}

Bilindiği gibi Mukaddime'yi devrinin, öncenin ve sonranın betimleyici diğer eserlerinden üstün tutan, varlık olan toplumu incelerken kullandığı özgün kuramsal çerçevedir (Issawi, 1969: 10; Lewis, 1970: 160, 136; Rosenthal, 1968: $3)$. Bu çerçeve içinde en çok bilinen ve neredeyse Haldun'la birlikte anılan kurgusal araç ise, "asabiye" düşüncesi ya da şematiğidir. Mukaddime ile asabiye arasındaki örtüşme o kadar yüksektir ki, yorumcuların mukaddimeyi yorumlama biçimleri çoğu kez asabiyeyi anlama biçimlerini yansıtır (Hassan, 1998: 208). Basit olarak asabiye sosyal-ekonomik yalıtılmışlık ile ilkel bir üst yapının ortaklaşa şekillendirdiği toplumu ya da topluluğu kenetlenmiş ve kenetlendiği ölçüde de sağlam kılan bir bilinç durumudur. Kelime anlamı itibariyle "korumak, kazanmak, harekete geçirmek, faaliyette bulunmak" gibi çağrışımlar yapan (Hassan, 1998: 231) ve çoğu kez de askeri bir ruhu 
karşılayan tanıdır asabiye (Gellner, 1984: 143). Kuramsal değeri bir yana, ${ }^{14}$ kabilelerin ve klanların sosyolojisini anlamamızı kolaylaştıran bir tarihi araçtır aynı zamanda. Yazar Kuzey Afrika gerçeğini bire bir karakterize eden kabileci dayanışmayı, dayanışmanın insanın olmazsa olmaz ihtiyacı savunma durumuna yaptığ1 olumlu katk1 nedeniyle övüyor. Herkes kendini korumak ister; ama asabiyeli bir birliğin parçası olanlar en kesin ve kapsayıcı şekilde bu amaçlarına kavuşurlar (Haldun, 1997a: 309). Asabiyet dış ve iç düşman tehlikesi karşısında toplumu oluşturan bireyler arasındaki dayanışmacı durumu karakterize eden genel kavramlaştırmanın adıdır (Haldun, 1990a: 352; Haldun 1997a: 329; Haldun, 1988a: 450). Bu bağlamı itibariyle siyasal olmaktan çok ahlaksal olan bir bağa karşılık gelir asabiye ve "biz" olmanın, "kendi" olmanın bilincini yansitır (Arslan, 1987: 114-124). ${ }^{15}$

Modern zamanların ulusal bilincine benzeyen asabiye tıpkı milliyetçilik de olduğu gibi yalnızca savunma içgüdüsünün emrinde değil her şeyden önce. Aynı zamanda saldırı amacıyla da kullanılabiliyor. İnsanın varoluş güvenliğini garantileyen asabiyeci kaynaşma, rahatlıkla başka insanların dünyalarına yönelmiş açık bir tehdit haline gelebiliyor. Aslında bitmek tükenmek bilmeyen kabile savaşlarının nedeni de asabiyenin Haldun'un anlattığının tersine saldırgan amaçlara hizmet etmesi gerçeğiyle ilgili olmalıdır. ${ }^{16}$ Kabile kültürü varlığını ve her türlü yapma gücünü öteki üzerinden elde ediyor. Kabileci bütünlüğü ayakta tutan ve dahası çoğu kez değişmesini ve eleştirilip sorgulanmasını engelleyen kötüye özdeş dış gerçeklik. Asabiyetçiliğin gelişmiş tekrarı milliyetçilikte de benzeri sıkıntıları görmek mümkün. Asabiyenin en kusursuz hali kişinin kişiselliğinden sıyrılarak bireysel ve ayrı (özerk) iradesini

14 Haldun'un asabiye anlatısı kavramlaştırdığı bedevilik-hadarilik ayrımı ile Tönnies'in cemaat-cemiyet ayrımını hatırlatıyor. $\mathrm{Bu}$ açıdan modern sosyolojinin antik bir tamamlayıcı niteliğinde. Tönnies ve Haldun'un teorileri arasındaki benzerlikler için bkz.(Orçan, 2004: 81).

15 Asabiyenin farklı anlamları için bkz.(Hassan, 1998: 196-222) ve (Arslan, 1997: 111152).

16 İbni Haldun'un asabiyeyi iki ayrı anlamda kullandığg, kabileler arasında kan dökmek sonucunu doğuran şovenist tür asabiyeyi yerdiği, buna karşı kenetlenme bağlamında siyasal olanı kuran asabiyeyi ise övdüğü iddia edilebilir. İddia Haldun'un saldırı ya da savunma, yağma temelli kör kan dökücülüğü benimsemediği, yalnızca birlik ruhunu ve bu ruhtan çıkan gücü işlevsel açıdan onayladığı yargısına bitişiktir. Bu yarg1 gerçekleri yansıtmaz. Haldun eserinde kabileci şiddet eğilimi açıkça yermemiştir. Benzeri bir şekilde savaş olgusuna da barış odağında normatif bir karşı çıkış yapmaktan kaçınır. Hatta realist bir tarzda savaşı kazanmak için yapılacakları ve yapılamayacakları sayar. Ayrıca kuramının ana bağlamı ilkeli üstün ve üste göstermeye yöneliktir. Bahsi geçen karş1 görüş için bkz.Arkan/Bozgöz, 2003: 192). 
toplumsal iradenin içerisinde eritmesi sayesinde mümkün olacaktır. Böylelikle bir ile bütün arasındaki ontolojik ayrım zihinsel açıdan sona erecek ve kenetlenme tamamlanacaktır. Ancak bu insanın bir faktör olarak yok olması sonucuna götürür bizleri. Düşünür açık bir şekilde homojen toplumdan yana tavır takınmaktadır. Toplumsal çeşitlilik ona göre "güçlü, sağlam devletle" bağdaşmayacak bir niteliktir" (HALDUN, 1997a: 378). Haldun'un sosyal çeşitliliği bir zenginlik değil de, birliğin sağlanması açısından güçleştirici, dolayısıyla olumsuzlayıcı bir öğe olarak ele alması önemli ölçüde kuramının baş unsuru kabileci-asabiyeci sistemi ile ilgilidir. Haldun'un düşünsel ufku herkesin birbirine benzediği ve ancak bu benzerliğin geçerli bir gücün altyapısını oluşturabileceği düşüncesiyle sınırlıdır. O farklılıktan kaynaklanan benzemezliğin yaratacağı çatışmanın sağladığı dinamizm üzerine kurulu bir toplumu değil, farksızlıktan kaynaklanan benzerliğin yaratacağı uyumun sağladığ1 tek örneklilik üzerine kurulu bir toplumu yeğlemektedir. Haldun'daki toplumsal kenetlenme düşü, kişinin özerk ve özgür varlığını sonlandıran bir mekanik dayanışma biçiminden öte bir anlama gelmemektedir. ${ }^{17}$ Kaldı ki bu anlam sosyolojik betim olarak filozofun realist siyasal çerçevesini destekler niteliktedir.

İbni Haldun'un siyasal teorisi iktidar ve hükmetme arzusunu insanların siyasete olan duygularının temeli gören bir Makyevelist tınıyı yansıtır (Ritter, 1978: 2; Garaudy, 1965: 56; Rosenthal, 1978: 1-17). Ancak bu benci-bencil öz işlevsel bir bağlamla sentezlemiştir. Rasyonel insan, üstün beklentilerini ancak etkin bir siyasal örgütün içinde (toplumda) gerçekleştirebilir (Hassan, 1998: 5859). O halde siyasetin amacı iktidardır; bu amaca ancak benzerlik üzerinden yetkinliğini kotarmış bir toplumsallıkla ulaşılabilir. Böylesi bir çözümleme uygarlığ1 mümkün k1lan ve kendi nedenselliğini kendi belirleyen devlet nosyonunun da başlangıç noktasıdır (Rosenthal, 1968: 80). Bu tanımlama biçimi bağlamında doğaları gereği zalim ve kötü olan insanların birbirine zarar vermesini engelleyen özünde iyi ve yararlı olan bir kurumdur devlet (Kurtoğlu, 2006: 43). Asabiye işte bu iyi devletin hem siyasal öznesi, hem de üzerinde egemenlik ilişkilerinin sürüp gideceği nesnesidir. Asabiye ile devlet arasındaki bağ birbirine bağlı üç önerme ile ortak bir formüle dönüştürülebilir: (1) Toplumda farklı asabiyeler vardır. Güçlü olan kazanır ve diğerlerini kendine itaate zorlar. (2) Asabiyenin amacı bir genel iktidar olacak (devleti ele geçirecek kadar) güçlü olmaktır. (3) Devleti güçlü kılan maddi olanaklar zemininde asabiyeci dayanışma olduğuna göre devletin çöküşü asabiyenin

17 Asabiyenin bir mekanik dayanışma biçimi olduğu görüşü için bkz. (Kızılçelik, 2006: 83). 
çözülmesi ya da daha güçlü bir asabiyenin ortaya çıkışı ile mümkün olabilir ancak (Haldun, 1997a: 329-330, 376-7; Haldun 1990a: 97, 353-4, 416; Haldun, 1988a: 423-496). Demek ki Haldun asabiye aracılığıyla "güç" ile "iktidar" arasına, birinden diğerine geçişi mümkün kılan sivil bağı kodlar (Rabi, 1967: 61, 65, 67). Kodlama biçimindeki katılık asabiyeyi siyasal yabancılaşmaya karşı bir sivil doğallık olarak gösteren ve bu haliyle onu aklayan "iyimserliğin" yersizliğini de gösterir niteliktedir. ${ }^{18}$ Kuramı tüketme noktasında asabiyeye dahil tek olumlu not bu kabil bir bağlamın devlete laik bir moral temel sağlama noktasındaki benzersiz üstünlüğü ile ilgili olacaktır. Haldun asabiye aracıllğıyla siyasetin dinden bağımsız doğasına dikkat çekmiştir (Hassan, 1998: 179; Kurtoğlu, 2006: 43).

\section{DEĞIŞMEK ILE DEĞIŞMEMEK ARASINDA HALDUN'DA HAREKET \\ Ídealizm ve Düzenin Mükemmelliği}

Haldun'un düzeni onaylayan kurgusallığ 1 , filozofun değişime ve değiştiren nedenlere nasıl baktığının sorgusu ile sonuca bağlanabilecek niteliktedir. Çünkü düşünürün materyalist değişimci etiketi ile yorumlanmasına yol açan sosyali nedensellikle birlikte düşünen pasajları vardır. ${ }^{19} \mathrm{Bu}$ pasajlar özellikle toplumsal yapıyı iktisat ile birlikte andığı yerlerde yoğunlaşır (Boulakia, 1977). Haldun edebiyatında "değişimi”" açıklamaya yönelik üç başat argüman belirgin bir şekilde ilgili sosyolojiye siyasal tadını vermektedir. Bahsi geçen argümanlar sırasıyla, (1) değişimi katmanlı saiklerle açıklayan ve onu düzenin kabul edebileceği sınırlar içinde formüle eden evrimci paradigma, (2) olguyu bir bozulma olarak gösterip değişmeyi ahlaki açıdan sorgulanabilir hale getiren Platonik tasarı, (3) ve son olarak değişimi diyalektik doğasıyla anlatıp fakat başlangıcını düşünceye bağlayan ve dolayısıyla onu dünya gerçeklerinden ve sorunlarından uzaklaştıran idealist tutumdur. Mukaddime de hem dinsel tümdengelim şeklinde bir idealizm, hem evrimci anlayış, hem de bozulma düşüncesi vardır.

Haldun, özetinin insan kavrayıșına ilișkin bölümlerinde, varlığın birimleri arasında tinsel bir hareketlenmenin doğallığından bahsetmektedir.

18 Böyle bir tını için bkz.(Kozak, 1994: 94).

19 Haldun edebiyatında açıkça "değişim doğa yasasıdır, her şey zorunlu olarak değişir" der. Bkz. (Haldun, 1997a: 212). Ama sonra değişimlerin döngüselliğini, bir anlamda değişerek hep aynı kalmayı ve bununla beraber yavaşça değişmeyi değişimin doğa yasası katına çıkarır. 
Ruh, ak1l ve melekler birbirini tetiklemektedirler. Bu durum, harekete, hareket de değişime yol açmaktadır (Haldun, 1997a: 244). Filozofa göre insan zorunlu olarak toplumsaldır. İnsanın toplumsal ontolojisi tanrının eseridir (Khaldun, 1989: 89-91). Haldun tanrıyı bir "ilk neden" olarak görür ve tasarlar (Kurtoğlu, 1999: 252). Filozof sosyal-maddesel nedenselliğinin üzerine doğal bir ruhsalkurgusal nedensellik öngörmektedir. Bu nedenle Haldun sosyolojisini tinsel başlangıçlar kavramlaştırmasıyla, dolayısıyla ruhçulukla ve idealizmle ilintili görebiliriz (Sorokin, 1972: 17). Konumuz açısından bizi ilgilendiren şey ise idealizm ile düzenin yedeği konumundaki geleneksel düzen yanlısı duruş arasındaki gizli açık ilişkidir. İdealist bir varlık anlayışı, bu anlayışı benimseyenleri uyum adı altında mükemmelliyetçi bir bütünlük idealine, böylesi bir kabul de kolaylıkla siyasallaştırılabilen bir "social harmony" çizgisine sürüklemektedir. Dünyayı tasarımsal yetkinlik içinde görmek isteyen kişi, genellikle bu tasarıyı bulanıklaştıran insan etkinliklerini; örneğin onların (insanların) sıkıntılarını, isyanlarını ve gerçekliliğin mükemmel olmadığını kanıtlayan devinimlerini görmemek-duymamak eğilimindedir. İdealist akıntı iktidarın korunması-kollanması sorununa seçkinlerin elini güçlendirecek bir tarzda yaklaşır. Dünyayı ve bu dünyanın insanlarını aslında olmadıkları şekilde, olduğundan daha iyi, daha sorunsuzca gösterme kaygısını ifade eder idealistin yaşama bakışı. Her gerçek olan rasyoneldir şeklindeki Hegelci tanı idealist bakışın kendi yetkinliği için rafine bir örnektir. Gelenekçi siyaset tam da bu noktada devreye girmektedir. Değişimin yavaşlatılması, statükoya değişimin seyrine dair ayrıcalıklı bir yer verilmesi, düzenin tüm kurum ve kuralları ile meşrulaştırılması, düzenden yana olmayanların bir biçimde ötekileştirilip değersizleştirilmesi gibi birbirini tamamlayan uygulayış tarzlarına sahip geleneksel siyaset, idealizmin gerçeklerin belli bir kısmını görmeme eğilimine, siyasal sıva olarak yardım eder. İktidar yanlısı tutum alt katmanların acılarına karşı ilgisiz bir tutumu ilkeselleştirerek, bir "yok sayma" eylemselini ön plana çıkarabilir. Bu kabil bir düşünme stilinin en ortodoks şekli ise, yok saymak sınırında durmayarak politik eylemini yok etmeye taşıyan faşizmdir. Faşist uygulama yok saydıklarını yok ederek iktidarı o hep arzu ettiği pürüzsüz topluma kavuşturur. Böylelikle toplum idealist dogmatizme uygun bir şekilde kusursuzlaşmış olur. Tabii Haldun faşistlikle suçlanmamaktadır ya da Haldun tarzı bir iktidar kavramlaştırması faşizmle. Ancak ondaki tonu belirgin idealizm geleneksel seçkinci siyasete açık kapı bırakmaktadır. Bu açılan kapıdan ise düzeni meşru görme-gösterme eğiliminde diğer düşünceler içeri girmektedir. Dahası "yok saymak" eğer bir aklama belirtisi ise, Haldun da epeyce çok şeyi yok saymaktadır. Mesela makalenin üzerine değerlendirmeler yaptığı Mukeddime'de, kölelik kurumu bir olgu olarak betimlenmez. Kaldı ki sorun betimlemekten kaçındığı konulardan çok sadece betimlediği konularla ilgilidir. 
- Ankara Üniversitesi SBF Dergisi • 63-1

Haldun da tarafsızlık ve taraf tutma ironik bir şekilde iç içe geçmiştir. Makale yazarı bu şüpheli tarafsızlı̆ 1 bir yok sayma ve dolayısıyla iktidardan yana olarak var olma işareti olarak gibi algılamaktadır.

\section{Evrimci, Devrime Karşı}

Haldun'un anlatısını iktidar yanlısı kavrayışa yaklaştıran ikinci öğe evrimciliktir. Evrim düşüncesi kök anlamı itibariyle nicel değişikliklerin zamanla nitel değişiklere yol açacağına dair bir sanıyı anlatır. Değişimin nasılını açıklayan bu anlatı, değişen varlık olarak insan ele alındığı taktirde ya da onun bir beden büyügü toplum, ${ }^{20}$ kolaylıkla siyasal bir işarete dönüşür. Evrimci eylemsellik "adaletsizlik karşısında eylem" ve "düzenin meşruluğu" bağlamlarını iki biçimde etkiler: (1) Öncelikle, değişimin yavaş yavaş, uzunca zamana yayılmış bir şekilde ve bünyeyi sarsmadan dolayısıyla dengeci bir şekilde gerçekleşmesi, bu etiketlendirmeye uymayan değişimleri değersizleştiren, en azından olumsuzlayan bir değerlendirmeyi mümkün kılmaktadır. Evrim saptaması devrimler yoluyla dünyanın başkalaştııılması yöntemini olumsuz anlamda tartışmalı hale getirir. Eğer doğaya ve insanın doğasına en uygun değişme tarzı evrim ise, devrimsel talepler baştan bir irrasyonelliğe sahiptir diyebiliriz. Oysa devrimci tepkiler genellikle düzenden memnun olmayanların o düzeni daha adil, özgürlükçü ve eşitlikçi kılma çabalarına aracılık eder siyasal düzlemde. Ya da en azından evrimci sürüklenişe karşı bir haklılık inancını, bir eylem dayanağında kabullenmemeyi anlatır devrim (Camus, 1990: 11). (2) Ayrıca evrimcilik düzen içindeki hegomonik ilişkilerin devamlılığı anlamında, hakim öğelere kendilerini değişen şartlara göre yeniden inşa etme imkanını da verebilir. Böylesi bir imkan, tarihin yaratımı sırasında gerçeklik haline gelirse, değişim düzenin meşruluğuna iyileştirici katkı sağlamayan bir illüzyona indirgenmiş olur (Kettler, 1981: 17-58). Bu çözümleme tarih bilinci açısından yeniden kodlandığında, siyasi tarihte düzenin sahiplerin daha çok evrimcilik, mağdurlarının ise devrimcilikle tarihe ve dolayısıyla kendilerine şekil vermek istedikleri sonucuna ulaşılır. Evrimsel

$20 \mathrm{Bu}$ arada toplumu insanın bir beden büyüğü olarak tanımlayan söz dizimi tesadüfi değildir; en azından Haldun'daki "organizmacı" anlayış ile uyum içindedir. Uygarlık yaşlı insanlara benzer, ilkellik ise genç insanlara, bir oğlun büyüyüp, sonrada yaşlanması gibidir devletin doğumundan ölümüne değin geçirdiği evreler, ne toplum ne devlet bir kez yaşlanmaya yüz tutunca, bu süreç reformlarla geri döndürülemez. (Haldun, 1997b: 15-19 ve 224). Organizmacı anlayış, gelenekçinin topluma bakışını simgeler. Bkz. (Çiğdem, 1997: 33. Ayrıca Haldun organizmadır tezi için (Kongar, 1985: 65) ve (Uludağ, 1988: 116). 
tutum salt bu nedenden dolayı onu dillendiren için bir muhafazakarlık göstergesi sayılabilir. Bir kişi ya da bir düşünür, düzenin hakimi değilse ya da kendini o hakimiyete yakın hissetmiyorsa, toplumu değiştirmede seçkine daha çok kontrol imkanı veren evrimci bir modeli neden benimser?

Haldun sosyolojisinde evrimciliğin izlerini sürmek istersek deşmemiz gerekecek bağlam "alışkanlık" olacaktır. İnsanların alıştığı dünyada alıştığı gibi yaşamasını açıkça olumlamaktadır Haldun (Haldun, 1997a: 231). Yaşamın dededen babaya pek değişmediği çoğu kez "güneş altında yeni bir şeyin"olmadığı kabile düzenini taraf olarak ve diğerlerini yererek övmesi bu manada evrimci tını için anlamlı bir örnektir (Haldun, 1997a: 311). Alışkanlıklardan birden kopmayı tehlikeli görür ayrıca. Yemek kültürü ile ahlak arasındaki ilişkiyi yorumladığı pasajlarda, insan için en sağlklısının eğer perhizinde bir değişiklik yapacaksa, onun doğasına en uygun olan yavaşça değişime göre bunu yapması olduğunu belirtir (Haldun, 1997a: 231). Belli bir sırayı gözeterek doğru olanı yapabilme kabiliyeti Halduncu evrimciliği ifade eder. $\mathrm{Bu}$ anlamda (birbirini izleyen aşamaların doğallığı anlamında) Haldun evrimcidir (Bogardus, 1960: 175).

Devrimselliğe karşı tutumu bilinçli evrimci tercihi ile sınırlı değildir elbette. Haklı olmayı yeterince anlamlı bir güç olarak görmez filozof. Devrimlerin ve isyanların başarısının ölçüsü bir güç kompozisyonuna dayanmaları ile ilgilidir. Devrim kabilesel dengeye ve o dengeye içkin çıkar örtüşmelerine dayandığ1 müddetçe başarılı olur (Haldun, 1997a: 370-371). Demek ki Halduncu çizgiye göre düzeni değiştirecek devrim de düzenin bir uzantısıdır. Tüm bu yorumların dayandığı ortak nokta ise, iktidarı elde etmek ve elde tutmanın "hak-haksızlık" odaklı değil, "güç-güçsüzlük" odaklı bir sorun olduğudur. Haldun edebiyatı "devrim" nosyonu özeli yargılamasında bir kez daha "araçsal akla" yaslanır. Şöyle ki, yaşamın olağan bağlamında güçlü ve haklı olmak olabilecek durumların en iyisidir, ama bu olamıyorsa, güçlü ve haksız olan, zayıf ve haklı olandan daha iyi bir konumda olacaktır. Haldun için de önemli olan güçtür. Ancak güçlü olursan haklı olabilirsin. Bu haliyle edebiyatı Machiavelli, Hobbes, Hegel ve Neitzsche gibi güç ahlakçı çizginin insana bakışını yansıtır (Bouthhoul, 1967: 17; White, 1960: 116; Becker/ Barnes, 1961: 200, 278). Ama tabii Haldun'a yöneltilen yaftalamalar ve devrim olgusu çerçevesindeki tartışma bir yerden sonra anlamsızlaşacaktır. Çünkü filozof devrim hakkına karşıdır. Sapık olsa dahi halifeye baş kaldırılması doğru değildir ona göre (Haldun, 1997b: 86). Bu yargıyı önemli ölçüde insan varsayımdan türetmiştir. Haldun'a göre insan olan tutumlarında aşırıya gitmez. Duygusal tepkimeler ve devrimler insanı insanlığından çıkarır (Haldun, 1997a: 223). Sonuç olarak denilebilir ki Haldun, devrimci eylemselliği gerçekleri kabul etmek ile gerçeklerden hareket etmek arasında bir yerde tanımlar. Devrimler 
- Ankara Üniversitesi SBF Dergisi • 63-1

olmamalıdır; ama oluyorsa da güçlüyü iktidara getiren geleneksel anlayışça denetlenen bir mantığın vesayeti altında olmalıdır. Bu son kayıt da gösterir ki devrim nosyonuna bakış noktasında Halduncu çizgi önemli ölçüde Aristotelesçi kabullerden hareket etmektedir. ${ }^{21}$

Haldun'un düzene yönelik onayıcı tutumunun arkasında devrimlerin yaratacağı kaosun olağan duruma vereceği sınırsız zarar önemli ölçüde etkilidir. Filozofun katıldığı Aristotelesçi kaygılar arka planında bir eros-logos karşıtlığından meşruluğunu alır. Haldun'a göre insan doğası gereği kötüdür. İnsanı kötü kılan tanrısal yanıyla rekabet halindeki hayvani özgünlügüdür (Khaldun, 1989: 263-284). Aklın bedeni kontrol etmesine benzer bir kesinlikle iktidar da toplumu kontrol etmelidir. "Mülk" insanın hayvansal yanını denetleyen toplumsal akıldır (Kurtoğlu, 1999: 253). Güvenliği sağlayacak bir egemene ihtiyaç vardır son kertede. Egemen güvenliği koruyarak aynı zamanda insanın insan olma potansiyelini hayvan doğasına karşı da korur. Haldun'daki Machiavellist siyaset anlayışı makale içinde iki önemli tartışma üzerinden tekrar yorumlanacaktır. Haldun siyaset felsefesinde hükümdar, otorite, güç odaklı bir çözümleme yapar (Ülken, 2000: 258-9), bu çözümlemenin kendisi Halduncu tanıtlamanın kalbi olan asabiye düşüncesinin habercisidir. Ayrıca Haldun'da güçlü olana öykünme bir yerden sonra zayıflara karşı küçümsemeye dönüşür. Haldun'da ötekileşmeyi incelediğimiz bölümde notlandıracağımız bu ön yargılı tutum yeterince güçlü olmayanların önce siyaseten, ardından da ahlaken kınanması ve ahlaksızlıkla suçlanması ile kendi tamlığına erer. ${ }^{22}$

\section{Bozulma Düşüncesi, Platon'un İzinde}

Mukaddimede izine en çok rastlanan düzen yanlısı kavramlaştırma biçimi felsefe tarihinin meşhur savı Platonik bozulma düşüncesi ile ilgilidir. Bozulma kuramı insanlığın nesnel ya da varlığın tinsel geçmişinde bir dönemi, bir biçimi "altın çağ" olarak gören ve zamanın akışı gerçeği karşısında, insanın değişimini bir gerileme olarak gösteren felsefi anlatıdır. Popper'a göre Platon, "bu temel tarih yasasını, bütün yaratılmış ya da türetilmiş şeyler için geçerli kozmik bir yasanın bir bölümü olarak görmektedir. Akış halindeki bütün şeylerin, bütün türetilmiş şeylerin çürümesi kaçınılmazdır" (Popper, 2000: 35). $\mathrm{Bu}$ anlatının kendisi ve onun tarihin değerlendirilmesindeki kullanılış biçimi ilerleme düşüncesiyle açık bir çelişki içindedir. Bir dünyayı geriye döndürme çabası, ama bu çabadan beklenen sonuç gelmezse de değişmekte israr eden 
dünyayı karalama amacı ilgili felsefenin arka plan özetleridir. Ĕger insan sürekli bir düşüş içindeyse, dünyanın sürekli iyiye gittiği ve özellikle de insan çabasının bu gidişi hızlandırdığına dair önyargısal düşünce anlamsızlaşır. ${ }^{23}$ Tabii böyle bir anlamsızlaşma en genel anlamda "her şey boş o halde her şey değersiz ve değersiz olan hiçbir şeyi (dolayısıyla her şeyi) yapmaya da (yaşamak dahil) gerek yok şeklinde bir hiççiliğe yol açabilir. Ama bozulma düşüncesi top yekün olarak tüm insan eylemselliği ve o eylemselliğin doğal sonucu olan insan gerçeğini olumsuzlamadan çok, yaşadığı dünyadan ve onun kuruluş biçiminden memnun olmayanların o dünyaya muhalefetini olumsuzlamaktadır. Her türlü değişimin bozulma olduğunu en çok göremeyenler, bu değişimde kendi iyilerini arayanlardır. Bu bağlamda denilebilir ki eşitlikçi kavganın savunucuları, eşitsizlikçi düzenin savunucularından farklı olarak "değişime", dolayısıyla da kötülüğe daha yakındırlar. Bozulma mitosu insanın çabasıyla dünyayı daha iyi kılma gayretine karşı inançsızlığı anlatır. İnsanın etkenliğine bakış, insana bakışın ip uçlarını da içinde barındırmaktadır. Bir varlı̆̆ın eylemlerine inanmayan o varlığın kendisine de inanmayacaktır. Haldun önemli ölçüde benimsediği determinist dogmayı biraz da tarihin nesnel sürükleyicileri karşısında insanın zayıflığını, öznel anlamsızlığını vurgulayarak savunmaktadır. Demek ki filozof insanı, değişim gerçeğinin yegane kaynağ 1 (değiştiren özne) olarak görmemektedir. İnsan dünyayı değiştirebilir; amaların ve şartların izin verdiği müddetçe. Bu amalar ve şartlar üzerinde ise, çoğu kez bir etki gücü yoktur onun. Çünkü şart iklimdir ya da yaratıcı-kurucu akıl olarak tanr1.

Kentlilerin kabilelerde yaşayanlara göre ne derece kötü ve ne kadar fazla "kirlenmiş" (Haldun, 1997a: 298-299; Haldun 1989b: 299; Haldun 1991b: 868) olduğunu anlatırken kullanır bu bozulma kavramını. Ama daha esnek bir anlayışla ele alırsak bütün kitap satır aralarında böyle bir mantığ fisıldar. Kentlileri ileri olmaktan kaynaklanan bir gerilik içinde gören İbni Haldun kabileleri ise, geri olmaktan dolayı bir ilerilik içinde betimler. Her şey tersine dönmüştür onun sosyolojisinde. İnsan yetkin-kusursuz bir ahlaki başlangıca sahiptir. İyi insanlığın geleceğinde değil, insanların geçmişindedir. Bedevi ahlakını övmesi (Khaldun, 1989: 253-8; Haldun, 1990a: 309; Haldun, 1997a: 298; Haldun, 1988a: 420) hem rrkçılığın kıyısında bir ayrımcılık söylemdir, hem de maddi yaşam ile ahlak arasında bir neden-sonuç ilişkisi söylemi. Bedevi insanlarının ahlaklı olmasının sebebi bu insanları var oluş durumu olarak

$23 \mathrm{Bu}$ toplam aynı zamanda Rönesans ile birlikte iyice belirginleşen bireyci rasyonelliğin zamanı insanileştirmesi ve içselleştirmesi süreçlerinin zorunlu bir devamıdır. Yorum için bkz. (Heller, 1978: 1-2). 
Ankara Üniversitesi SBF Dergisi • 63-1

kavrayan zor yaşam koşullarıdır. Doğal olanın uygar ile yer değiştirmesi tarihselinde bedevi kendini koruma iç güdüsünden başkalarına hükmetme seviyesine evirilir (Arslan, 1987: 128-9). Hegelci kavramlarla ifade edersek umrana geçişle sonuçlanan toplumsal evrim süreci insanın doğal varlık olmaktan akılsal varlık olmaya terfisidir (Kurtoğlu, 1999: 261-2). Demek ki Halduncu terminoloji içinde uygarlaşma otantik doğanın yitirilmesi anlamında bir bozulma, ama aynı zamanda akıla ait olanın ön plana çıkması anlamında bir ilerlemedir.

Siyaset teorisi literatüründe "altın çağlar" mitosu Rousseau'nun elinde uygarlığa karşı eşitlikçi düzenin savunuluşu biçimine sokulmuştur. $\mathrm{Bu}$ savunuluşun kendisi ve uygarlığa özgülediği belirteçler, uygarlık çoğu kez adına kurum dediğimiz birliklerin bir toplamı ya da bileşkesi olduğundan Aristoteles'in birlikler düşüncesinin etkisi altındadır. Aristoteles'e göre her birlik eşitsizlikçidir (Aristoteles, 1990). Devletten dine, aileden eğitime kurumların yaşayabilmesi ve doğalarına içkin gelişimi tamamlayabilmeleri yöneten-yönetilen ayrımına uygun bir değişim-dönüşümü kabullenmelerine bağlıdır. İtaat eden ile edilen arasındaki farkın azalması birliğin dağılmasına yol açar. Haldun da aynı argümanı kendi özgünlüğü içerisinde tekrarlar. Ona göre, "öğeler, bileşiminde eşit olarak bulunduğunda, "mizaç", hiçbir zaman gerçekleşmez. Gerçekleşmesi için öğelerden birinin, ötekilerin hepsine baskın gelmesi, ötekilere egemen olması gerekir" (Haldun, 1997a: 381-382).

Her birliğin eşitsizlikçi oluşu savı, düzene muhalif düşünüşte uygarlığın eşitlikle bağdaşmayacağına dair popüler bir dogmaya dönüşmüştür. Eşitlikçi siyaset ya Rousseau'da olduğu gibi mutlak bir uygarlık reddine ya da sosyalistlerin yaptığı üzere belli başlı kurumların (devlet ve din, hatta aile) eşitlikçi devinimin devrimsel-evrimsel sürecinde yok olacağ 1 biçiminde mistik bir inanışa ulaşmıştır. Anarşistler ise, Rousseau ile Marks arasında konumlanabilecek bir tutuma sahiptirler. ${ }^{24} \mathrm{Bu}$ tartışma bağlamında düzen karşıtlarının uygarlık eleştirisi ile Haldun'un böyle bir sonuca yorulabilecek paragrafları aynı amaca yönelik değildir. Haldun uygarlığı ilkel eşitliğin bozulmuşu olarak değil, daha çok en az değişen dolayısıyla en uyumlu model

24 Godwin, Proudhon, Bakunin ve Kropotkin'in politik düşüncelerini Klasik Anarşizm adı altında yorumlayan George Crowder, anarşizmin düşünsel çizgilerini özet halinde formüle ettiği eserinde, bilimsel iyimserlik düşüncesi, uygarlık eleştirisi, özgürlük ve eşitlik tutkusu ile mülkiyet karşıtlığını bu ideolojinin özü olarak betimler. Bu betimlemede ilginç olan ise, Rousseau'ya çağcıl bir düşünür olarak değerlendirilebilecek Godwin'den (1756-1836), Marks ve sonrası konjonktürü özümseyen Kropotkin'e doğru (1842-1921) anarşizmin Rousseau ekseninden giderek Marks eksenine kaydığı yargısıdır. Bkz.(Crowder, 1999). 
olan kabilenin bozulmuşu olarak görür. ${ }^{25}$ Onun temel sıkıntısı değişerek eşitlikten uzaklaşan insanlarla değil, değişerek değişmemekten uzaklaşan insanlarla ilgilidir. $\mathrm{Bu}$ yüzden kurumlardaki neredeyse doğal siradüzenci örgütlenme, onda insanlığın geleceğine ilişkin bir endişeye yol açmaz. Ama Haldun sosyolojisini muhafazakar kılan asıl öğe, her türlü değişimi olumsuzlayabilecek bir sürekli düşüş düşüncesine "bozulmaya", kuramında verdiği yerden öte, bu düşünceyi çevrimsel bir tarih anlayışının içine hapsetmesindeki kurnazlığında aranmalıdır (Sorokin, 1976: 159). Şöyle ki, her şeyin sürekli kötüye gitmesi, bu gidişi algılayan insanlık bilincine eylemselliğin terki yönünde güçlü bir motivasyon etkisi yapmaktadır. Ancak bu etkinin yıkıcı gücü hiçbir şeyin kötüye ya da iyiye gitmediği, aslında ne yaparsan ve ne yöne gidersen git yine aynı yere varacağına dair çevrimsel tarihin yıkıcılığı ve kısıtlayıcılığ 1 karşısında önemsiz kalır. Kentsel yaşamı toplumsal yaşamın son aşaması olarak gören Haldun, onun da bozulacağını belirtir (Haldun, 1997a: 299). O halde yine herkes kırsal yaşama dönecektir, sonra tekrar kentsel yaşama ve tekrar kırsal yaşama. Bu değişimlere konu olan insan kendini fark1 ile anlamlandırma şansına sahip değildir. Bir anlamda (Stoacı bir anlamda) yazgısının kölesidir.

\section{HALDUN'DA AYRIMCILIĞIN ÍKTIDARI}

\section{Íklimler Kuramı Arka Planında Normal-Anormal Ayrımı}

İklimlerin yaşam ve siyasal yaşam üzerindeki etkisi siyasal düşüncenin tarihinde üç önemli düşünür aracıllğıyla takip edilebilir. Bunlar sırasıyla Aristoteles, İbni Haldun ve Montesquieu'dur (Kışlalı, 1990: 21-22). İklimler kuramının iktidar yanlısı siyasal düşünce içerisinde ayrıcalıklı bir yeri vardır. Çünkü iklimler düşüncesi evrimci-gelenekçi algılayışın kültürel mitosuna hizmet ederken, bir yandan da yine düzen savunusu ile sik sik yan yana gelebilen ayrımcılığa dayanak sağlamaktadır. Bu sav onu kullananların elinde ya Montesquieu örneğinde olduğu gibi bir dünyayı yavaşlatma, tarihi tersine çevirme aracına (Şenel, 1996: 349-355) ya da Aristoteles de dile geldiği üzere belirgin bir dışlayıcılık argümanına ${ }^{26}$ dönüşmektedir. Kısaca iklimler düşüncesi

25 Platon ile Haldun arasındaki koşutluk bozulma düşüncesi ile sınırlı değildir. Platon'daki kabile kolektivizmi ve orantılı eşitlik (bkz. Popper, 2000: 87-96) prototip özellikler olarak Haldun' da da vardır.

26 “....soğuk ülke insanları Avrupalılar, cesur ama zekaca geridirler. Bu nedenle özgür yaşarlar ama iyi, sürekli yönetimler kuramazlar. Sıcak ülkelerin insanları, Asyalılar, zeki ve bulucudurlar; ama cesaretleri kıt olduğu için her zaman buyruk altında köle gibi yaşamışlardır. Bu iki halkın oturdukları ülkelerin arasındaki ılıman ülkelerde 
kuzey, güney ve orta iklim kuşaklarının insanlarının iklimsel etkilerden dolayı, farklı karakterlere, dolayısıyla farklı siyasal kurumlara sahip oldukları görüşünü ifade eder. Tüm bu mantıki başlangıca dayandırılacak ilk toplumsal sonuç ise, evrensel en iyi yönetimin olanaksızlığıdır. Evrenseli bir kurgu haline getiren ve onu yerelin maddi gerçekliliği karşısında önemsizleştiren iklimci düşünüş genellikle topluma bakışı bilimselleştirmek gibi olumlu bir sonuca katkı sağladığ 1 için övülmüştür (Morris, 1997: 95-100). ${ }^{27}$ Ancak başka dünya özlemiyle ortaya atılan her türlü en iyi evrensel tasarımı, genelde bu dünyadan memnun olmayanların başvurduğu bir modeldir. Dolayısıyla bu tür tasarımları anlamsızlaştıran ve ona karşı var olanı ve var olmuş olanı üstün tutan iklimler düşüncesi muhafazakarca bir amacı kolaylamaktadır denilebilir. Her biçimiyle deneylerden ve deneyimlerden bağımsız istekler, yeni özlemler ve o özlemleri hayata geçirecek ani adımlar için son derece umut kırıcıdır iklimler düşüncesiyle ifade edilen. ${ }^{28}$ Farklı iklim kuşakları farklı insan ve toplum tipleri yarattığına ve iklimlerde öyle kolay kolay değişmediğine göre, o ülkenin en eski kurum ve kuralları o ülkede coğrafyanın belirlediği özel koşullara en uygun olanları işaret ediyordur. Demek ki devrimci değişiklikler içlerinde doğayla ve toplumların doğasıyla çelişen ve giderilmesi de mümkün olmayan bir akılsızlı nüvesi/özü taşırlar. Devrimi olanaksızlaştıran ve evrenseli önemsizleştiren iklimci nosyon aslında realist çevre teorilerinin yarattı̆̆ 1 hümanizm sorununa dikkat çekmektedir (Garaudy, 1965: 56; Sherwani, 1978: 419-411). Geçmişi makul görmek eşitsizliği onaylamak anlamına gelebilir.

İbn Haldun açık bir şekilde coğrafi olayların sosyal yaşam ve milletlerin kaderleri üzerinde etkisi olduğunu dile getirir (Sati El-Husri, 2001: 176; Ülken, 2000: 233) Haldun'da bir eğilim olarak doğanın insan üzerindeki determinasyonunu karakterize eden iklimci düşünce, düzenin geçmişiyle çelişik değişimlere kuşkuyla bakılmasını öğütler bizlere. Bu öğüt Montesquieu örneği bağlamında düzenin meşrulaştırılması gibi bir yakıştırmayı da daha inandırıcı kılmaktadır. Haldun'da ardılı Montesquieu gibi geçmişin aklını aklayan bir tarih anlayışını ve bu kabil bir tarih anlayışının bize benimsetebileceklerini benimsemektedir (Shackleton, 1961: 302; Gates, 1967: 415-422). Dahas1, bu

oturan Helenler, hem cesur hem zeki olduklarından, hem özgür yaşayan hem de en iyi yönetimleri kuran efendi halktır" (Şenel, 1996: 117).

27 İklimci anlayışın bilime olumlu katkısı yargısını ihtiyatla karşılamak gerekir. İklimin de içinde yer aldığı coğrafyacı kestirim ve bu kabil bir kestirimin bilimsellik noktasında yarattığı çıkmazlar için bkz.(Sorokin, 1994: 102-157).

28 Devrimci eylem meşruluğunu geçmişteki ve bugündeki gerçeklerden değil, adaletsizliğe karşı adaleti temsil eden gerçekleşecek olanlardan alır (Mannheim, 1995: 143) ve (Ağaoğulları/Köker, 1997: 191-194). 
kuramdaki en tehlikeli yan, kuramın insanlar arasındaki farklarla doğanın koşullandırmaları arasında kurduğu düşünsel bağlantıdır. İklimler düşüncesi insanlığın eşitsiz varoluşunu doğanın bir gereği gibi sunulmasını kolaylaştırır. $\mathrm{Bu}$ da rkç̧ılı̆̆a yol açar. Haldun'a göre 1lıman kuşağın insanlarındaki-bir anlamda kendisinin de dahil olduğu kuşağın insanlarındaki-üstünlük yalnızca uygar olmak bakımından değil, aynı zamanda insan olmak bakımından da söz konusudur. Haldun insanı ahlaki bir şekilde tanımladıktan (Haldun, 1997a: 134) sonra iklimlerle ahlaki yetkinsizlik ve yetkinlilik arasında bir doğru orantı kurmaktadır. Temellendirmesinin kritik öğesi "normal" kelimesi aracılığıyla anlatmak istediğidir. Haldun'a göre iklimler normal insanı yaratır; normal insan ise ahlaklı insanı. Bu anlamda erdem coğrafyayla sinırlanarak kendi tamlığına ulaşır (Haldun, 1997a: 215-6; Haldun, 1990a: 193-4; Haldun, 1988a: 331).

\section{Ölçülülük ve Gerçeği Makulde Aramak}

Haldun benimsediği ölçülülük ahlakı gereği normali en yetkin olarak görme eğilimindedir (Haldun, 1997a: 216) Düşünce tarihinde Aristoteles'den beri "doğru orta" ilkesi olarak her şeyin en ortasında, dolayısıyla en uçta bulunmayanında bir ek üstünlük görme alışkanlığı var. ${ }^{29} \mathrm{Bu}$ alışkanlık her şeyden önce belli bazı insani unsurları diğerleri karşısında üste ya da tersten okursak, bazı kesimleri alta görme amacına hizmet etmektedir. Dolayısıyla "normal" kavramı onu kullananlara, hiyerarşik evren ve insan tablosunu meşrulaştırma ve ek olarak bu sıradüzenlilik içerisinde kendinden olana önde ve kusursuzlaştırılmış payeler verme anlamına geliyor. Haldun'un çöl Arapları ile ilgili sözleri de tam olarak böyle bir anlayışın ifadesi. Onların, "Renkleri daha duru, daha parlak, tenleri daha arı, biçimleri daha eksiksiz, ahlakları sapmalardan daha uzak, daha bozulmamış, bilgileri algılama güçleri, kavrayışları daha keskin, daha yeterlidir" (Haldun, 1997a: 227) Ancak normalin Aristoteles'in kullandığı şekliyle bir değişimleri yavaşlatıcı, uçların egemenliğini önleyici unsur olarak yüceltilmesi ideolojik açıdan daha anlamlıdır. Çünkü normal insanların fazla olduğu, ölçülü insanların toplumun en kalabalık katmanının oluşturduğu toplumlarda, devrimlerin patlaması olasılığı azalır. Düzen sosyolojik açıdan en sağlam temellerine oturtulmuş olur. Normalin savunuluşundaki 1srar, muhafazakarların her yerde görmeyi arzuladıkları ve bozulmasını en büyük siyasal ve sosyal tehlike olarak gördükleri dengenin korunması gerçeği ile ilgilidir. Ortayı, ölçüyü ve en iyiyi ifade eden denge, normaller sayesinde daha güvende olacaktır. Çünkü normal

29 Genel olarak Aristoteles ahlakı, özel olarak ise, "ortak akıl” kavramının erdem merkezli çözümlenmesi için bkz.(Akarsu, 1982: 98-118). 
varlığına içkin psikolojisi gereği hiçbir zaman ölçüsüz ve dolayısıyla alış1lmamış şeyler istemeyecektir (Aristoteles, 1999: 54-55). Ölçülülük kişinin kendisiyle ve çevresiyle yürüttügü her türlü psikolojik ve sosyal ilişki açısından değerleri gözetmesi şeklinde özetlenebilecek gelenekçi bir ahlakı açığa vurur aslen. Filozof "ölçülülüğü"- bir yapıyı korumak onu yıkmaya göre daha dingin bir tutum stratejisi gerektirdiğinden ve devrimsellik bir taşma, bir ek enerji savrulması olduğundan-devrimin reddi ve geleneğin onaylanması ile eşitsizlikçi insan ilişkilerine sadakat amaçlarına hizmet edecek şekilde savunur. Bu savunu uçları dışlayan şekilde ve tüm tanıtlamalarına sinmiş olarak edebiyatına kendi özgünlügünü vermektedir (Hassan, 1998: 293-294).

\section{SONUÇ YERINE}

Makale Mukaddime üzerine yaptığ ideolojik/öznel okumada filozofun düzeni mazur ve makul gösteren bir felsefe yarattığını savladı. Bu savunma içinde en çok altı çizilen nokta Halduncu siyaset anlayışının olanların/olmuş olanların dünyasına yönelik etik politik yakınlığıdır. Daha açık bir anlatımla Haldun'u iktidara en çok yaklaştıran ve siyasi edebiyatına rengini veren öğe olanlar lehine yürüttüğü olması gerekene olan anlamlı ilgisizliğidir. Haldun anlatısı okuyucusuna gelecek inancı ve geleceğe karşı sorumluluk bilinci kazandırmaz. Filozof, tutumunun yönünü belli etmeyen bir tarafsızlıkla hareketlerine yön vermektir. Bugünün bilim çevreleri için örneklenen bir model olmuştur sırf bu yönüyle. Oysa insanlığın temel meseleleri hakkında sessiz kalmak, bir anlamda susmak da bir tercihtir. Tarihsel deneyimler göstermiştir ki, bilim adamına değerlerden bağımsız davranışı salık veren pozitivizm bu özü ile düzeni destekler nitelikte bir ideoloji haline gelmiştir. Haldun'undaki gibi yalnızca betimleyici olmak, en çok çözümleme yaptığı yerlerde bile, böyle davranan bilinci yıkım derecesinde insanlıktan çıkaracaktır.

Haldun'da görülen, insanlık acıları karşısında gözünü kırpmayan, profesyonel bir bilimsel duruştur. Aynı zamanda da ahlaken tartı̧̧malı bir duruş. Eşitliği sorun olarak ele almayan, hatta sıradüzenci dünyayı tepeden tırnağa doğal gören, insanı doğa, toplum ve tanrı karşısında edilgenleştiren, ondaki özgür iradeyi önlenemez ve geri çevrilemez yasalar ardında boğan ve her şeyi dünyanın ilerde daha iyi bir dünya olacağı inancını dahi önemsizleştiren bir muhafazakar kaostur Haldun sosyolojisinde bizlere anlatılan. Mukaddime "dün", "deney-deneyim", "organizma" ve "geleneğin" özlü bir toplamıdır. Haldun sosyolojisi yarını dışlayan ve incelediği kurumların değişmesi sorunsalı hakkında kanaat beyan etmeyen mekanik bir düşünselliği ifade eder (Gibb, 1963: 1-17). Bu durum Haldun'a yöneltilmiş iktidar yanlıs1 pozisyon alış yaftalamasını güçlendirir. Çünkü ancak bir gelenekçi (Haldun 
örneğinde gelenek savunusu sofistike bir realizme karşılık gelir) dün ve bugünün bir biçimde kendini tekrar edeceğine samimi bir şekilde inanır ve bu inancından kotardığı ön yargılarına dayanarak geleceği düşlemez.

Haldun'un düzeni destekleyen felsefesini iktidarcı parçacıklar içeren bir tanıtlamalar toplamı olmakla itham etmek özü itibariyle (her ne kadar dile getirilen İbni Haldun üzerine çalışmaların genel seyri dikkate alındığı oldukça iddialı ve kışkırtıcı bir sav olsa da) "betimleyici" bilimin sınırları içinde kalmayı kabul etmek anlamına gelecektir. Kanımca Haldun'a yapıştırılan "realist-gelenekçi" etiketi ancak ideoloji-metodoloji ekseni ve İslam özelinden iktidar-bilim ilişkisi üzerinden yorumlanırsa siyaset felsefesi literatürü açısından özgün bir yere oturtulur.

Makale İbni Haldun'u aynı anda metodolojisi itibariyle "devrimci", ideoloji itibariyle "muhafazakar" olarak tanıtır. Dahası düzeni destekleyen filozofun iktidarı desteklediği savlamaz. Ortaya çıkan tablo en azından ilk verileri itibariyle şaşırtıcıdır. Metodoloji ile ideoloji, düzen ile iktidar arasındaki fark ne kadar büyüktür ki, birinden bir ötekine geçerken filozofun kavramsal rengi değişir? Ya da yeniden formüle edersek İbni Haldun düzenin yanında ama iktidarın yanında değil midir; dahası bir filozof hem devrimci hem de evrimci nasıl olabilmiştir? İbni Haldun'un tarih felsefesinde özelleşen kuramsal bilmecesini aydınlatma noktasında "organik entelektüel", "organizmacılık" ve "pozitivizm" gibi üç kavramsal araca başvurulabilir. İbni Haldun çalışması ile toplumsal yapıyı pekiştiren, dini değerleri geleceğe aktaran, gelenekleri hatırlatan, içinde yaşadığ 1 toplumu özü itibariyle devam ettiren bir kimse, halk diliyle ifade edersek bir "bilge adam", kavramın özgün terim karşılığı itibariyle bir "literatus"tur. ${ }^{30}$ Literatus Gramsci'nin "organik entelektüel" diye tanımladığ 1 kişileşmiş işlevsel durumun özünü ifade eder. İbni Haldun'un organik entelektüel olarak ilanı organizmacılık ile güç ahlakı, organizmacılık ile Aristotelesçilik arasındaki devamlılık açısından hayati derecede önemlidir. $\mathrm{Bu}$ tespit ayrıca özel olarak bu makale genel olarak da tüm toplumbilimsel çalışmaları bağlayan sosyal bilimler paradigmasının "zamanda geri taşımaya" dair bildik kaygılarının yeniden gözden geçirilmesine neden olmalıdır.

Farklı zamanların ve farklı mekanların ortak bir usun ölçütüne göre ve hatta ortak bir usun belli bir zamandan aldığ 1 kavramların ölçütüne göre yargılanamayacağına dair postmodern duyarlılık İbni Haldun üzerine yapılan

30 Literatus:Çalışması ile toplumsal yapıyı pekiştiren, dini değerleri geleceğe aktaran, gelenekleri hatırlatan, içinde yaşadığı toplumu özü itibariyle devam ettiren kimse. Ayrıntılı bilgi için bkz.(Mardin, 1984: .9-16). 
siyaset felsefesi çalı̧̧masının ortaya koymaya çalıştı̆̆ 1 gibi tutarsızdır. İbni Haldun hem bir realist, hem bir organizmac1, hem bir pozitivist, hem de bir organik entelektüeldir. Ama İbni Haldun'u tanımlamakta kullandığımız kavramların hiçbiri onun çağına ait değildir. Onun "mülk" dediği şey bizim "devlet" diye adlandırdığımızın şeye karşılık gelmez mesela. Peki İbni Haldun'u 20.yüzyıla 20.yy kavramlarını 13.yüzyıla taşımamıza olanak sağlayan hareket ettirici mekanizma nedir? Şüphesiz ki insanın tarihselliği. İnsanın tarihselliği 20.yy diye kendine özgün bir zaman kesiti olmadığ 20.yüzyılın kendinden önceki tüm zamanların sorunları, yanıtları, kişileri ve bilgilerini içerdiğini anlatır. Dolayısıyla İbni Haldun pozitivisttir ya da realisttir dediğimizde 20.yy ile 13.yüzyılı karş1laştırmıyor; 20.yy 20.yy olurken çoktan zamanın içinde erimiş ve artık 13.yy olmaktan çıkmış bir zaman parçacığını 20.yy ile karşılaştırıyoruz.

Tarih felsefeleri ya da özelinde tarih felsefesi üzerine kurulmuş siyaset felsefesi çalışmaları ve hatta makalede yapılmaya çalışıldığı üzere özgün siyaset felsefesi çalışmaları üzerinden kotarılan bilimsel incelemeler anokranizme düşme tehlikesinden kaçınırken "tarih bilincini" yitirme tehlikesiyle yüz yüze gelmektedir. Tarih bilinci özü itibariyle geçmiş ile bugün arasındaki ortaklığın süregelen bilincidir. Böylesi bir bilinci diline/düşüncesine yansıtamamış bir değerlendirme "gerçekliği" yakalama noktasında sorunludur. Anokranizm kaygısı bizi karşılaştırma olasılıklarını azaltan suni bir gündeme, gerçeğin yerini almış bir illüzyona mahkum edecek ölçüde aklımızı esir almamalıdır.

Makalenin kullandığ 1 yöntemin aklanması ile ilgili son bir hatırlatma daha yapılabilir. Bizler modern çağın insanları olarak kavramlarımızı "değişim" olgusunun nesnel sınırları içinde algılıyoruz. Pozitivizm sanayi çağına ait bir bilim ideolojisi. İbni Haldun ise tarım toplumu içinde yaşadı. Pozitivizm kesin olan bilgiyi bulmaya çalışıyor. İbni Haldun da benzeri bir uğraş vermekte. $\mathrm{Bu}$ durumda ne yapmamız gerekir? Kavramların değişimi yansıttığını kabul edersek İbni Haldun'a "pozitivist" demek büyük bir hata olacaktır. Ya peki tersi doğruysa? Kavramlar değişen dünya içinde değişmeyen tutku ve sorunların cisimleşmiş halleri ise? Kesin bilgiyi arayan kişi olgucu ise Haldun olgucudur. Sanayi çağında kesin bilgiyi arayan kişi olgucu ise Haldun olgucu değildir. Değişmeyenin referans kabul edildiği her türlü çözümleme zamanda sürekliliği vurgular. Değişim ise başlangıçlar ve bitişler ile aralıklıdır. Usun hareketi her zaman kısa ömürlü olur. Bu tutsak ikilimi içinde ve "bütün ayrımların yapay olduğu" ön bilgisi rehberliğinde geçmişten bugüne doğru eklemeler yaparak, bugünden geçmişe doğru eksiltmeler yaparak Descartesçi bir yöntem içinde hareket etmek en doğru yol gibi görünmektedir. Böylelikle hem statik inceleme-dinamik inceleme ayrımının arkasındaki sosyal bilimsel problemi es 
geçen ve dolayısıyla pozitivizmi eksik algılayan bilim yapıcılarına karşı olguculuğun avantajlarından, hem de olguculuğun işlemez hale geldiği yerde nedenleri tarihte geriye götürmeye eğilimli realist bilim felsefesinin bereketli zemininden gerçeği bulma ve yorumlama noktasında yararlanabiliriz.

\section{Kaynakça}

AĞAOĞULLARI, Mehmet Ali/KÖKER, Levent (1997), Tanrı Devletten Kral Devlete (Ankara: İmge Yayınlar1).

AHMED, Akbar (2002), "Ibn Khaldun's Understandings of Civilizations and the Dilemmas of islam and the West Today," Middle East Journal, 56/1: 20-45.

AKARSU, Bedia (1982), Ahlak Öğretileri (İstanbul: Remzi Kitabevi).

AKIN, Asım (1998), Tarih Boyunca Masonluk (Ankara: Hacettepe-Taş Yayınları).

AL-AZMEH, Aziz (1994), “ibni Haldun,” MILLER, David (ed.), Blackwell'in Siyasal Düșünce Ansiklopedisi (Ankara: Ümit Yayınları).

ARISTOTELES (1999), Eudemos'a Etik (Ankara: Dost Yayınları) (Çev.: Saffet Babür).

ARISTOTELES (2000), Politika (İstanbul: Remzi Yayınları) (Çev.: Mete Tuncay).

ARKAN, Rüstem/BOZGÖZ, Faruk (2003), "Kabile, Așiret, Asabiyet ve Savaș,” Doğu Batı, 24: 173. 210.

ARSLAN, Ahmet (1987), Ibni Haldun'un Ilim ve Fikir Dünyası (Ankara: Kültür ve Turizm Bakanlığ Yayın(arı).

BAĞCE, Emre H. (2005), “ibni Haldun’un İdeoloji Kuramı:Karșılaştırmalı Bir Çözümleme," Doğu Batı (Sayı 31): 105-123.

BARNES, H.E/BECKER, Howard (1961), Social Thought From Lore to Science (New York: Dover Publications).

BARTHOLD, W. (1963), İlam Medeniyeti Tarihi, (Ankara: MEB Yayınları).

BEATTY, Joseph, (1983), “The Rationality of the "Original Position”:A Defense,” Ethics, 93: 484495.

BOGARDUS, Emory S. (1960), The Development of Social Thought (New York: David Mckay Press).

BOULAKIA, J.D.C. (1977), "Ibn Khaldun:Fourteenth Century Economist," Journal of Political Economy, 79/2: 112-145.

BOUTHOUL, Gaston (1967), Siyaset Sosyolojisi (İstanbul: Remzi Yayınları) (Çev.: Ali Türkay Yazıcl).

BURTT, A.E. (1964), The Metaphysical Foundations of Modern Science (New York: Doubledy Anchv).

CAIRNS, Grace E. (1971), Philosophies of History:Meeting of East and West in Cycle Pattern Theories of History (Connecticut: Greenwodd Press).

CAMUS, Albert (1990), Başkaldıran Insan (Ankara: V Yayınları) (Çev.: Tahsin Yücel).

CARLYE, R.W. I CARLYE A.J. (1962), A History of Medieval Political Teory in the West (Edinburgh and London: William Blackwood and Sons Ltd).

CHIROT, Daniel (1985), “The Rise of the West," American Sociological Reviw, 50/1: 181-195;

CORBIN, Henry (2000), İslam Felsefesi Tarihi, Cilt 2, Ibni Rüșd'ün Ölümünden Günümüze (İstanbul: iletișim Yayınları) (Çev.: Ahmet Arslan).

CROWDER, George (1999), Klasik Anarșizm (Ankara: Öteki Yayınları) (Çev.: Sinan Altınparmak).

ÇiĞDEM, Ahmet (1997), “Muhafazakarlık Üstüne,” Toplum ve Bilim, 74/2: 32-51.

DEMiR, Ömer (2000), Bilim Felsefesi (Ankara: Vadi Yayınları). 
DUVERGER, Maurice (2002), Siyaset Sosyolojisi (İstanbul: Varlık Yayınları) (Çev.: Șirin Tekeli).

EDWARDS, Paul, (1970), The Encyclopedia of Philosophy, C.3-4, (New York: Macmillan Publishing Co.Inc. Free Press).

FALAY, Nihat (1978), Ibni Haldun'un Iktisadi Görüșleri (İstanbul: İstanbul Üniversitesi İktisat Fakültesi Yayınları).

GARAUDY, Roger, (1965), Sosyalizm ve İslamiyet (İstanbul: Yön Yayınları) (Çev.: D.AvcıoğluE.Tüfekçi).

GATES, Waren E. (1967), “The Spread of Ibn KHaldun's Ideas on Climate and Culture,” Journal of the History of Ideas, 78/3.

GEERTZ, Clifford (1964), “Ideology as a Cultural System,” APTER, David (Der.), Ideology and Discontent (New York: Free Press).

GELLNER, Ernest, (1984), Thought and Change (London: Weidenfeld-Nicholson).

GIBB, H.A.R, (1963), "Studies in Comtemporary Arabıc Literature," Egyption Modenists (London: Bulletion of the Scholl of Oriental Studies VII).

GÜRiZ, Adnan (2001), “Adalet Kavramının Belirsizliği,” GÜRiZ, Adnan (ed.), Adalet Kavramı (Ankara: Türk Felsefe Kurumu Yayınları).

HABERMAS, Jurgen (1993), “ideoloji” Olarak Teknik ve Bilim (İstanbul: YKY Yayınları) (Çev.: Mustafa Tüzel).

HASSAN, Ümit (1998), İbni Haldun'un Metodu ve Siyaset Teorisi (İstanbul: Toplumsal Dönüșüm Yayınları).

HASSAN, Ümit (2006), “Mukaddimeye dair ve sair,” Toplum ve Bilim, 107: 7-42.

HEGEL, G.W.F. (1995), Tarihte Akıl (İstanbul: Kabalcı Yayınları) (Çev.: Onay Sözer).

HELLER, Agnes (1978), Renaissance (London: Routledge ve Kegan Paul) (Çev.: R. E Allen).

HENRY, Dermond Paul (1967), “Medieval Philosophy,” EDWARDS, Paul (ed.), The Encyclopedia of Philosophy (New York: Macmillian Publishing).

HiLAV, Selahattin (1975), 100 Soruda Felsefe El Kitabı (İstanbul: Gerçek Yayınları).

HOBBES, Thomas (1993), Leviathan (İstanbul: Yapı Kredi Yayınları) (Çev.: Semih Lim).

IBN HALDUN (1997a), Mukaddime (Ankara: Onur Yayınları) (Çev.: Turan Dursun).

IBN HALDUN (1997b), Mukaddime (Ankara: Onur Yayınları) (Çev.: Turan Dursun).

İBNi HALDUN (1990a), Mukaddime, Cilt 1 (İstanbul: Milli Eğitim Bakanlığı Yayınları) (Çev.: Zakir Kadiri Ugan).

IBNi HALDUN (1989b), Mukaddime, Cilt 2 (İstanbul: Milli Eğitim Bakanlığı Yayınları) (Çev.: Zakir Kadiri Ugan).

IBNi HALDUN (1989c), Mukaddime, Cilt 3 (İstanbul: Milli Eğitim Bakanlığı Yayınları) (Çev.: Zakir Kadiri Ugan).

IBNI HALDUN (1988a), Mukaddime, Cilt 1 (İstanbul: Dergah Yayınları) (Çev.: Süleyman Uludağ).

IBN HALDUN (1991b), Mukaddime, Cilt 2 (İstanbul: Dergah Yayınları) (Çev.: Süleyman Uludağ).

IBN KHALDUN (1989), The Mugaddimah: An Introduction to History (Princeton: Princeton University) (Ing.Çev.: Franz Rosenthal),

ISSAWI, Charles M.A. (1969), An Arab Philosophy of History (London: Batter-Turner Ltd).

KETTLER, David (1981), “Yabancılașma ve Olumsuzluk,” A. De CRESPIQNY, A, De/MINIQUE, K. R. (eds.), Çă̆daș Siyaset Felsefecileri (İstanbul: Remzi Yayınları).

KIŞLALI, Ahmet Taner (1990), Siyaset Bilimi (Ankara: İmge Yayınları).

KIVILCIMLI, Hikmet (1989), “ibni Haldun’un Gerçek Diyalektiği,” Bilim ve Ütopya, 57/1: 33-44.

KIZILÇELIK, Sezgin (2006), Sosyoloji I (Ankara: Anı Yayınları).

KONGAR, Emre (1985), Toplumsal Değișme Kuramları ve Türkiye Gerçeği (İstanbul: Remzi Yayınları). 
KOZAK, I. E. (1984), Ibni Haldun'a Göre Insan-Toplum-iktisat (İstanbul: Pınar Yayınları). KURTOĞLU, Zerrin (1999), İslam Düșüncesinin Siyasal Ufku (Isstanbul: Iletișim Yayınları). KURTOĞLU, Zerrin (2006), “ibn Haldun’la Çağımızı Okumak,” Toplum ve Bilim, 107/1: 43-65.

LACOSTE, Yves (1993), İbni Haldun: Üçüncü Dünyanın Geçmişi, Tarih Biliminin Doğuşu (İstanbul: Sosyalist Yayınları) (Çev.: Mehmet Sert).

LEWIS, Bernard (1970), The Arabs in History (London: Hutchinson Universtiy Library).

MACHIAVELLI, Niccolo (1999), Prens (İstanbul: Oğlak Yayınları) (Çev.: Rekin Teksoy).

MACLNTYRE, Alasdair (1988), Whose Justice? Which Rationality? (Notre Dame, Indiana:University of Notre Dame Prses).

MAHDI, Muhsin (1957), Ibn Khaldun's Philosophy of History:A Study in the Philosophic Foundation of the Science of Culture (London: George Allen \& Unwin).

MANNHEIM, Karl (1995), “İdeoloji ve Ütopya,” SEZAL, İhsan (ed.), Sosyoloji Yazıları (Bursa: Ekin Yayınları).

MARDIN, Şerif (2001), Din ve Ideoloji (İstanbul: İletișim Yayınları).

MARDIN, Şerif (1984), “Aydınlar Konusunda Ülgener ve Bir İah Denemesi,” Toplum ve Bilim, 24/1: 9-16.

MARKS, Karl (1993), 1844 El Yazmaları (İstanbul: Sol Yayınları) (Çev.: Kenan Somer).

MARROW, Raymond A. (1994), Critical Theory and Methodology (Thousand Oaks: Sage Publications Inc).

MERiç, Cemil (1997), Umrandan Uygarlığa (İstanbul: Ötüken Yayınları).

MILLER, David (1994), Blackwell'in Siyasal Düșünce Ansiklopedisi (Ankara: Ümit Yayınları) (Çev.: Bülent Peker/Nevzat Kıraç).

MORRIS, G.C. (1997), “Montesquieu ve Siyasi Tecrübenin Çeșitleri,” THOMSON, David (ed.), Siyasi Düşünce Tarihi (İstanbul: Şule Yayınları).

NISPET, Robert, (1994), “Muhafazakarlık," Sosyolojik Düşünmenin Tarihi (Ankara: V Yayınları) (Çev.: Erol Mutlu).

NODIA, Ghoia (1999), “Milliyetçilik ve Demokrasi," YAYLA, Atilla (ed.), Sosyal ve Siyasal Teori (Ankara: Siyasal Yayınları) (Çev.: Eralp Yalçın-Atilla Yayla).

ORÇAN, Mustafa (2004), “Cemaatten Cemiyete Türkiye'nin Modernleșme Pratiği," Muhafazakar Düșünce, 2: 71-91.

POPPER, Karl (2000), Açık Toplum ve Düşmanları (İstanbul: Remzi Yayınları) (Çev.:Mete Tunçay).

PARSONS, Talcott (1969), "An Approach to the Sociology of Knowlenge," Transactions of the Fourth World Congress of Sociology (Milan ve Stressa).

PARSONS, Talcott (1971), The Social System (London: Routlendge and Kegan Paul).

PORTER, Roy (1990), The Enlightenment (London: Macmillan Press).

POULANTZAS, Nicos (1988), “Kapitalist Devlet Sorunu," BELGE, Murat/AKSOY, Atilla (eds.), Kapitalist Devlet Sorunu (Istanbul: İletișim Yayınları) (Çev.: Yasemin Berkman).

RABI, M.M. (1967), The Political Theory of Ibn Khaldun (Leiden: E.J Brill).

RITTER, Hellmut (1978), “Irrational Solidarity Groups:A Socio-Psyshological Study in Connection with Ibn Khaldoun," Oriens, I:78-96

ROSENTHAL, E.I.J. (1967), Ibn Khaldun in Egypt (Berkeley-Los Angeles: University of California Press).

ROSENTHAL, E.I.J. (1968), Political Thought in Mediaval Islam:An Introductory Outline (Cambridge: Cambridge University Press).

ROSENTHAL, E.I.J. (1978), “Some Aspect of Islamıc Political Thought," Islamıc Culture XXII, Hyderabad. 
206• Ankara Üniversitesi SBF Dergisi • 63-1

SABINE, George (1991), Yakın Çağ Siyasi Düşünce Tarihi (Ankara: Gündoğan Yayınları) (Çev.: Özer Ozankaya).

SATI EL-HUSRI, (2001), İbn Haldun Üzerine Araștırmalar (İstanbul: Dergah Yayınları) (Yayına Hazırlayan: Süleyman Uludağ)

SHACKLETON, Robert (1961), Montesquieu: A Critical Bibliography (Oxford: Oxford University Press).

SHERWANI, H.K. (1978), "The Place of Oriental Thought in the Field of Political Science," Islamic Culture, II: 97-106

SUNAR, İlkay (1979), Düşün ve Toplum (Ankara: Kültür Bakanlığı Yayınları).

SOROKIN, P.A. (1962), Society, Culture and Personality (New York: Amerikan Book Campany).

SOROKIN, P.A. (1976), “Fluctuation of Social Relationships, War and Revolution," Social and Cultural Dynamics (New York: American Book Campany).

SOROKIN, P.A. (1972), Bir Bunalım Çağında Toplum Felsefesi (Ankara: Bilgi Yayınları) (Çev.: Mete Tuncay).

SOROKıN, P.A. (1994), Çağdaș Sosyoloji Kuramları Cilt 1 (Ankara: Kültür Bakanlığı Yayınları) (Çev.: M.Münir Rașit).

ŞENEL, Alaeddin (1996), Siyasi Düşünceler Tarihi (Ankara: Bilim ve Sanat Yayınları).

TiMUÇiN, Afșar (1994), Felsefe Sözlüğü (İstanbul: BDS Yayınları).

ULUDAĞ, Süleyman (1988), “Giriș: İbn Haldun ve Mukaddime," Mukaddime Cilt 1 (İstanbul: Dergah Yayınları).

URRY, John/KEAT, Russel (1994), Bilim Olarak Sosyal Teori (Ankara: İmge Yayınları) (Çev.: Nilgün Çelebi).

ÜLKEN, Hilmi Ziya (2001), Ahlak (İstanbul: Ülken Yayınları).

ÜLKEN, Hilmi Ziya (2000), İslam Düşüncesi: Türk Düşüncesi Tarihi Araștırmalarına Giriș (ìstanbul: Ülken Yayınları).

WHITE, Hayden V, (1960), "Ibnı Khaldun in World Philosohy of History," Comparative Studies in Society and History II (New York: McGraw-Hill).

YAYLA, Atilla (1998), Siyaset Teorisine Giriş (Ankara: Siyasal Yayınları). 